\title{
A ATHENAS BRASILEIRA NO PÓS-ABOLIÇÃO: EXPERIÊNCIAS NA ESCOLARIZAÇÃO PÚBLICA PRIMÁRIA
}

\author{
Ian Andrade Cavalcante \\ Universidade Federal Fluminense - UFF
}

\section{RESUMO}

Este artigo procura se debruçar sobre diferentes experiências vividas por diversos agentes da escolarização publica primária na cidade do Salvador, durante o período do pós-abolição, 1888-1903, utilizando as proposições da História Social. É fruto de pesquisas voltadas para a produção da dissertação de mestrado em Educação, intitulada: Pela instrucção dos filhos do povo: escolarização e cultura escolar na Salvador do pós-abolição. Utilizamos como procedimento teórico-metodológico o cruzamento de diversas experiências encontradas uma gama variada de documentação, além de bibliografia especializada e dados censitários, no intuito de elucidar diferentes versões sobre a escolarização e a cultura escolar na Salvador do pós-abolição. Procuramos analisar a relação entre instrução pública primária, raça e trabalho no centro urbano soteropolitano, além de dialogar sobre questões de gênero, raça e classe ligadas à escolarização pública primária. Foram de extrema importância os diferentes mapas escolares, relatórios e ofícios da instrução pública, que permitiram, além do já citado, algumas considerações sobre as relações entre os diferentes agentes envolvidos na instrução pública primária, dando destaque aos embates e tensões entre professores e delegados escolares.

Palavras-chave: escolarização; cultura escolar; experiências; pós-abolição.

\section{THE BRAZILIAN ATHENAS DURING POST-ABOLITION: EXPERIENCES IN THE PRIMARY PUBLIC SCHOOLING}

\begin{abstract}
This article seeks to look into different experiences of various agents of primary public education in the city of Salvador, during the post-abolition period, 1888-1902, using the propositions of Social History. It is fruit of researches related to the production of a Master's dissertation in Education, entitled: "For the instruction of the child of common people": education and school culture in the post-abolition in Salvador. We used as theoretical and methodological procedure the intersection of diverse experiences found in a wide range of documentation, as well as professional literature and census data, in order to elucidate different versions of schooling and school culture in the post-abolition in Salvador. We tried to analyze the relationship between primary public education, race, and work in this urban center, and established a dialogue on issues of gender, race and class linked to the primary public education. Extremely important were the different school maps, reports and requirements of public education, which allowed, in addition to the aforementioned, some considerations on the relationship between the different agents involved in the primary public education, highlighting the conflicts and tensions between teachers and school delegates .
\end{abstract}

Keywords: schooling; school culture; experiences; post-abolition. 


\begin{abstract}
"Outro sim, para poder funcionar com alguma regularidade, é preciso que V. Exa. [...] como e pela instrucção dos filhos do povo, se digne mandarprovel-a dos utensílios necessários conforme a relação que remeto $a V$. Exa. Aproveitando a opportunidade, apresento a $V$. Exa. os meus protestos de respeito e subida consideração." (Prof. Lucio Casemiro dos Santos, Rua do Passo, 1900).
\end{abstract}

\title{
1. Introdução.
}

Este artigo busca analisar, em partes, o processo de escolarização e a cultura escolar do período debruçando-se sobre as diversas experiências ${ }^{1}$ encontradas na documentação. Propomos colaborar com o conhecimento sobre a história social ${ }^{2}$ da educação para a cidade do Salvador, na Bahia, por meio de uma metodologia de trabalho em que o foco do historiador, seus problemas e perguntas, valorizam a escrita da história vista "de baixo". A operação nos permite conhecer outros aspectos sociais e culturais ainda não suficientemente estudados. Privilegia-se as experiências de classe, a cultura e os modos de vida diversos, as tensões e as lutas, ou seja, "há de se encontrar a estrutura na particularidade histórica do 'conjunto de relações sociais', e não em um ritual ou em formas particulares isoladas dessas relações” (THOMPSON; 2012, p. 248).

Desta maneira podemos perceber a presença de distintas versões sobre aspectos como relações entre família e instrução, relação entre matrícula, freqüência e faixa etária, dentre outras, por meio dos discursos dos agentes sociais envolvidos na escolarização soteropolitana do pós-abolição. Para além dessa percepção, tal bojo documental nos permite inferir sobre as tensões e embates, interesses e motivações envolvidos na Instrução Pública primária. Aqui discorreremos sobre a escolarização nos distritos por meio do cruzamento dos dados encontrados nos regulamentos voltados para o ensino primário e os ofícios enviados pelos delegados escolares, assim como os mapas escolares, que nos permitem observar as mudanças ocorridas. Concordamos com a operação historiográfica realizada por Marcus Aurélio Taborda de Oliveira e Sidmar dos Santos Meurer (2007) quando os autores se utilizam de relatórios da instrução pública e da legislação do Paraná para analisar o processo de escolarização na década de 1910. Eles explicam o caminho que percorreram em sua pesquisa, explicitando a busca pela confirmação ou críticas ao que pode ser encontrado na legislação, ou nos discursos dos legisladores.

Os mapas escolares constituem registro documental importante para o historiador que busca reconstruir aspectos históricos da cultura escolar e do processo de escolarização no período do pós-abolição e anos iniciais da Primeira República. Isso pode ser percebido, por exemplo, na documentação relativa à escola municipal de sexo masculino, no distrito da Conceição da Praia, na cidade do Salvador, regida pelo professor Guilhermino Gomes Barbosa de Castro. Por meio de um dos seus mapas de alunos, conseguimos obter o registro de 22 dias letivos no mês de fevereiro de 1898, incluindo duas aulas não realizadas em razão de uma reforma na casa-escola. ${ }^{3}$

A escolha por trabalhar com os mapas escolares se justifica pela densidade das informações a respeito dos processos de engendramento do cotidiano da escola. No entanto, concordando com a perspectiva de Diana Vidal (2008), na qual é preciso lembrar que os registros eram elaborados pelos mestres, com um propósito específico e de um lugar determinado. Os professores deveriam produzir documentos com o intuito de comprovar que estavam cumprindo com sua função, além de corroborar também a necessidade da existência de sua escola. (VIDAL, 2008).

Os mapas e registros serviam ao governo das escolas, destinados aos inspetores de ensino, para a produção de estatísticas e de dados de conhecimento e controle da população e de suas próprias ações. As estatísticas corroboravam e/ou justificavam as políticas e 
escolhas governamentais. A chamada "febre de estatísticas" (VIDAL, 2008), ocorrida no século XIX, atingiu o Brasil e fez com que se estabelecesse outra dinâmica na distribuição de recursos. Essa questão demanda uma reflexão sobre os limites de tais fontes históricas, tendo em vista as disputas políticas e provinciais por verbas e legitimação de seus projetos. Para esta pesquisa, foram utilizadas fontes estatísticas importantes, os censos demográficos do período. Ainda que levemos em consideração a fragilidade dos dados, os registros censitários de 1872, 1890 e 1906 são fundamentais para o estudo do perfil social da população da cidade do Salvador no pós-abolição (SENRA; 2006).

Como principais objetos de pesquisa para este trabalho estão os distritos da Sé, da Conceição da Praia e do Santo Antônio além do Carmo, situados no centro da cidade, e o da Penha, localizado um pouco mais distante da região central, mas ainda considerado urbano. Os dois primeiros (Sé e Conceição da Praia) foram criados em 1549 e 1623, respectivamente (SOUSA; 2006). O Santo Antônio além do Carmo foi um dos maiores distritos, e seus moradores eram em sua maioria negros de poucas posses. Já o distrito da Penha foi criado no ano de 1759 (SOUSA; 2006) e se caracterizou por ser local de moradia das classes mais pobres.

Mapa 01:

Planta da cidade do Salvador, década de 1880.

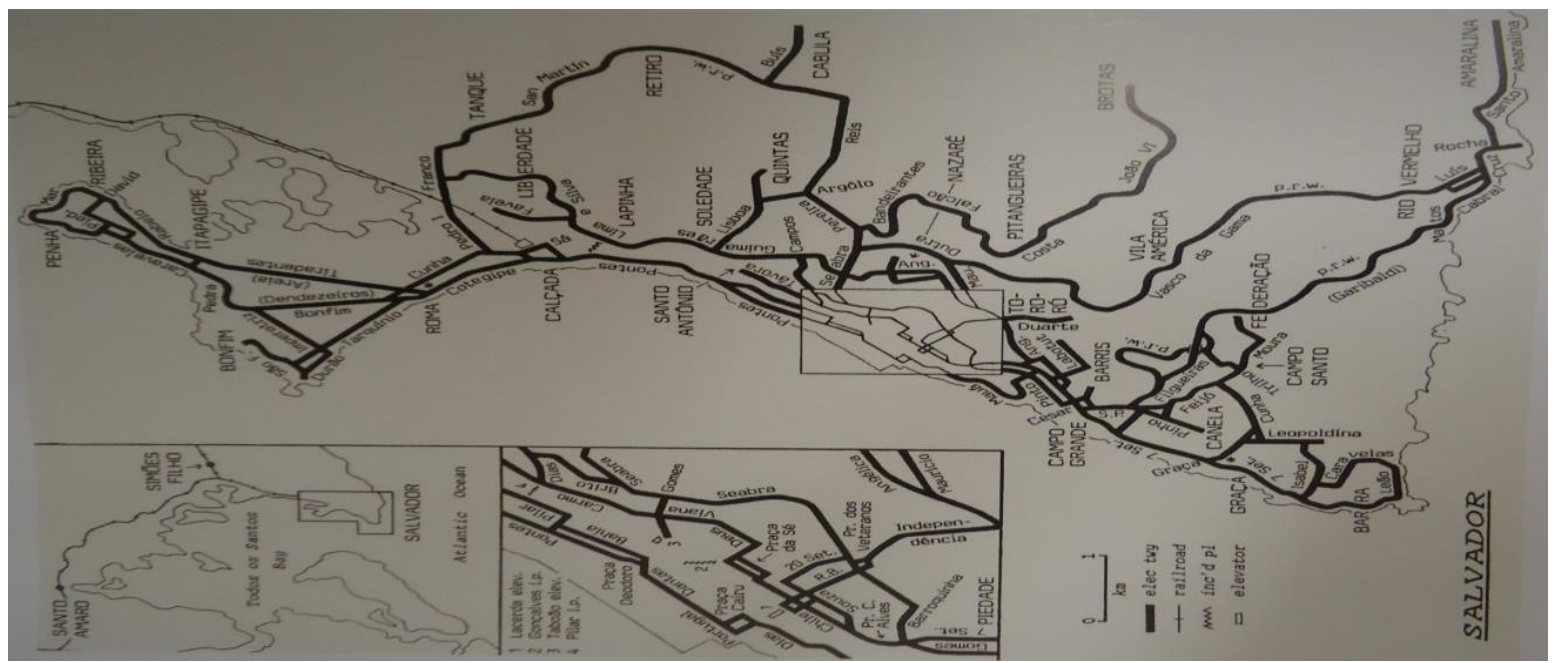

Fonte: BPEB: SAMPAIO, Consuelo Novais. 50 anos de urbanização: Salvador da Bahia no século XIX. Rio de Janeiro: Versal, 2005.

No mapa 01, podemos visualizar todos os distritos que fazem parte desta pesquisa, sendo que dois deles se encontram na cidade alta: Sé e Santo Antônio além do Carmo. Os outros, Conceição da Praia e Penha, se localizam na cidade baixa. No quadrado ampliado do mapa, podemos ver a Praça da Sé, coração do distrito e centro administrativo do município e do estado. Também é possível visualizar a Praça Deodoro, situada na Conceição da Praia, coração portuário da cidade do Salvador. Este distrito era populoso e possuía uma densa população negra, composta por trabalhadores urbanos ligados ao comércio e transporte de mercadorias.

À esquerda do quadrado ampliado no mapa, aparece o distrito do Santo Antônio além do Carmo, região de moradores com poucas posses, a maioria deles lavradores ou simplesmente descritos como pessoas que trabalhavam com "negócios". Um pouco mais à esquerda está o distrito da Penha, que ganhou destaque em nossa pesquisa por ter resultados relativos ao ensino primário sempre acima das demais regiões analisadas, além de ser o último distrito urbano. Essa área se encontrava afastada do centro urbano e, com as 
condições precárias do transporte público na cidade naquele período, a tarefa dos professores públicos primários ficava ainda mais difícil. A utilização de bondes puxados por burros começou no final do século XIX, e somente em 1903, Salvador inaugurou sua rede de iluminação elétrica. Esse distrito era habitado por maioria de sujeitos de poucas posses, negros, trabalhadores do campo e lavradores.

O processo de escolarização e a cultura material escolar constituem um campo de fundamental importância para a análise historiográfica do período do pós-abolição na cidade do Salvador. Cruzar os dados sobre a cultura urbana com o fazer-se $e^{4}$ da escola pública primária possibilita ampliar a perspectiva sobre o final do período imperial e começo do período republicano, marcados por intensos embates e tensões relacionados ao abolicionismo e à questão racial. É por meio dessa operação que iremos proceder nestas breves considerações.

\section{Instrução pública primária, trabalho e raça na cidade mais negra do Brasil.}

Em Salvador, no ano de 1872, segundo os dados censitários ${ }^{5}$, existia uma população escolar, alunos de 6 a 15 anos que Frequentam Escola que somavam um total de 7.176 alunos. Já aqueles que Não Frequentam Escola equivaliam a 19.246 meninos e meninas. O total da população em idade escolar, que frequientava e não freqüentava a escola, era de 26.422. Em um conjunto demográfico que chegava a 129.109 Almas, isso significa que 5,5\% das pessoas de Salvador deveriam estar nas escolas. Apesar disso, somente 27,2\% dos meninos e meninas em idade escolar estavam inseridos na escolarização soteropolitana.

O censo realizado em 1872 foi considerado por parte da historiografia como bem organizado e elaborado, enquanto o censo de 1890 sofreu severas críticas por estar incompleto (SENRA, 2006). Devemos levar em consideração as condições do período e todos os limites dos dados encontrados nos censos do final do século XIX. As informações em 1890 nos mostraram um total de População Escolar de 20.650, enquanto o Número de Matrículas era de 3.069. Havia 75 escolas para uma População Geral de 177.025. Isso equivale a dizer que $11,6 \%$ do conjunto de habitantes estavam nas escolas. (MENEZES, 2011, p. 25). Neste censo, esses foram os únicos dados encontrados.

Os números apresentados ajudam a compreender um pouco da importância da escolarização para o período em questão. Para tanto, um exercício possível é verificar como os dados relacionados a esse processo podem ser cruzados com informações sobre o trabalho urbano, especialmente se atentarmos para uma categoria laboral informal específica: os ganhadores de rua. Estes trabalhadores prestavam serviços de carreto, carregamentos e/ou descarregamentos, além de grande parte das atividades braçais que estivessem aptos a desempenhar. Em sua imensa maioria, eram trabalhadores negros, libertos ou escravos (até 1888), nascidos na África ou no Brasil, e ocupavam as ruas do centro de Salvador prestando seus serviços ou aguardando nos cantos, que era o espaço físico onde eles se estabeleciam. Essa categoria social se tornou o centro das preocupações republicanas na virada do regime monárquico para a República.

O estudo a respeito dos debates e propostas para a instrução primária no período da abolição, e no pós-abolição, não pode deixar de considerar a emergência da teorização científica e das práticas políticas de constituição da classificação social em critérios de raça. ${ }^{6}$ A princípio, o conceito de raça, de acordo com Larissa Viana (2007) é utilizado desde o período moderno, e possuía um significado relacionado a uma noção de comunidade, ou uma origem em comum. (VIANA, 2007, p. 41). Com o avanço da ciência moderna, o conceito começa a tomar contornos diferenciados, servindo de fundamentação teórica para justificar discursos científicos do século XIX, nos quais “(...) ganhou outro conteúdo, sendo apropriado pelas teorias biológicas então em voga (...)" (VIANA, 2007, p. 41). Para 
compreender e delimitar o racismo decorrente das relações sociais, seguindo as propostas da história social, utilizaremos além das contribuições de Wlamyra Albuquerque, Amilcar Pereira e Larissa Viana, o trabalho de Silvia Lara (2010, p. 17), quando aponta que o racismo se enraizou "no terreno das relações conflituosas entre sujeitos historicamente situados, mudando ao longo do tempo."

É preciso ter cuidado para não considerar as relações sociais e o destino das populações libertas na sociedade brasileira como simples resultado de uma herança escravista. Nessa perspectiva tradicional, que tem sido revisitada pela historiografia, a abolição seria somente uma conseqüência, um mero reflexo que não conseguiria produzir nenhum tipo de mudança. Seria um não-fenômeno, ao invés de ser encarada como um longo processo de lutas e disputas, no qual os escravos e negros livres e libertos tiveram participação ativa (MATTOS e RIOS, 2005). Também é necessário ter em mente que o contingente de ex-cativos não era homogêneo e estático em termos de seus pertencimentos sociais e culturais. Havia clivagens e grupos, com interesses diversos, inclusive no campo discursivo e científico sobre a raça. Como aponta Amilcar Pereira (2013, p. 48), o conceito moderno de raça (...) "é uma construção do pensamento científico europeu e norteamericano, (...) e se consolida a partir da segunda metade do século XIX, justamente durante o período em que o imperialismo europeu se fortalecia."

Como sugere a historiografia social, torna-se importante para os ex-escravos e seus filhos o significado de ser cidadão integrado ou de transformar-se em brasileiro. Flávio Gomes (2005) nos lembra que "entre a herança e o legado do cativeiro estavam suas identidades reinventadas em parentescos, visões de mundo, lembranças e recordações" (GOMES, 2005; p. 12). Quanto mais escura a cor da pele, maiores os mecanismos discriminatórios excludentes embasados na raça, impostos por alguns setores dominantes da sociedade da época. Negros e mestiços enfrentaram também dificuldades para obter educação, cargos públicos e vagas em concursos públicos, sem falar na intimidação e violência policial, o que os colocou em desvantagem, "limitando seu acesso a ganhos sociais" (DANTAS; 2010, p. 144). Wlamyra Albuquerque e Walter Fraga Filho indicam que essa lógica racial também influenciou, não oficialmente, decisões do governo. Um exemplo foi a escolha em combater a febre amarela, que atingia os imigrantes europeus, em vez da tuberculose, que afetava principalmente os negros em função de suas precárias condições de vida na capital federal.

Os mesmos autores também investigam a experiência de libertos, no meio rural e urbano da Bahia, no período do pós-abolição. Albuquerque nos traz os conflitos decorrentes da racialização das relações sociais, apurando, por exemplo, o caso de comerciantes africanos "súditos de cor preta" (ALBUQUERQUE; 2009, p. 47), que queriam voltar ao Brasil no intuito de fazer negócios, mas foram impedidos, encaminhados para a deportação. Ele destaca ainda a relevância do Conselho de Estado, o qual, apesar de não possuir funções deliberativas, tinha "(...) um papel político importante na arquitetura do governo imperial (...)" (ALBUQUERQUE; 2009, p. 66), inclusive em relação às questões raciais e, por conseguinte, no desfecho das empreitadas comerciais dos sujeitos negros. Fraga Filho, por outro lado, nos traz as percepções e expectativas sobre as novas relações que poderiam se formar com o fim da escravidão, no pós-abolição. Ele aponta que esse período teve como uma de suas principais características o fato de os ex-escravos terem recusado "(...) tanto a continuidade de ritmos de trabalho e formas de autoridade vigentes na velha ordem escravista, como buscaram condições para viver sem "sujeição"” (FRAGA FILHO; 2004, p. 203).

Em relação ao final do Império, especificamente a última década, as pesquisas de João José Reis (2000) sobre os ganhadores ${ }^{7}$ na cidade do Salvador nos apresentam indícios 
a respeito da organização desse grupo de trabalhadores, composto majoritariamente por negros libertos, crioulos e africanos. O autor mergulhou no universo do trabalho urbano da capital baiana nos fins da escravidão, aprofundando a análise no ano de 1887, a fim de compreender as entrelinhas nos acessos e possibilidades desse tipo específico de atividade. Esses dados são importantes para perceber como as políticas de controle sobre a população negra, e pobre, estavam sendo tecidas no final do período escravista. Verificamos um maior controle exercido pela polícia sobre os ganhadores, principalmente na década de 1880 , com casos relatados pelo autor, por exemplo, no distrito da Conceição da Praia. João Reis aponta que "tratava-se de disciplinar uma população negra livre e liberta" (REIS, 2000, p. 202), tendo em vista que o número de escravos nesse período já era mínimo.

Tal controle ficou explícito no ano de 1887, tendo em vista que o número de registros municipais de ganhadores era alto, o que aponta para uma preocupação maior em relação a essa população às vésperas da abolição (REIS; 2000). Interessante notar que havia escolas noturnas para adultos em Salvador durante as décadas de 1870 e $1880^{8}$, e a primeira a ser fundada foi a do professor Joaquim Saturnino Santos, em 1871, justamente na Conceição da Praia, distrito que possuía grande número de ganhadores.

$\mathrm{Na}$ Bahia, quase não participaram imigrantes europeus na mudança do trabalho escravo para o assalariado ${ }^{9}$, o que se refletiu nos ganhadores, pois sua grande maioria viera do recôncavo e da África. O maior número de $\operatorname{cantos}^{10}$ estava situado nas freguesias da Conceição da Praia e do Pilar. Esses espaços geográficos, segundo Reis, eram "verdadeiras instituições africanas em Salvador" (REIS; 2000, p. 216), por conta da grande presença tanto na constituição quanto na preponderância na liderança dos cantos. Dois deles, na zona portuária, eram completamente africanos em 1887. A relativa autonomia que esses trabalhadores, negros, possuíam, ainda antes da abolição, preocupava os senhores de engenho, que tinham em mente a necessidade de mão-de-obra, pois os libertos se recusavam a trabalhar em suas terras (REIS; 2000).

Outra importante questão apontada por Reis trata sobre as categorias de cor e a classificação racial encontrados nos registros sobre os cantos. Entre as diferentes categorias, encontramos preto, pardo, fula, mulato, caboclo e cabra, para denominar os diferentes tipos de mestiços presentes. Fato interessante trazido por Reis diz respeito à mudança quanto à nomenclatura crioulo, que é substituída por preto - termo anteriormente utilizado para denominar os negros africanos. Como bem lembra o autor, "a classificação racial é em grande medida situacional, depende do contexto, da posição social de quem classifica e de quem é classificado" (REIS; 2000, p. 234). Por último, torna-se crucial atentar para a entrada de mestiços e brancos no tecido social dos ganhadores, até então um setor de hegemonia de negros africanos. Segundo João José Reis, este fato pode estar relacionado à situação econômica difícil do período. (REIS, 2000, p. 235-236).

Encontramos o mapa da Aula primaria nocturna estabelecida à rua do Silva na freguesia de Santo Antonio em 11 de junho de $1888^{11}$ e na relação de alunos constavam quatro ganhadores. Além deles, havia profissões como pedreiro (1), ferreiro (1), alfaiate (1), roceiro (1), chapeleiro (1), marceneiro (1), estivador (2), seleiro (2), criado (2), aguadeiro (1), sapateiro (2), saveirista (1), carpina (1) e três estudantes que não tinham profissões assinaladas, de 14, 18 e 19 anos. Nos deteremos um pouco na análise sobre os dados dos ganhadores, por serem os de maior número e muito provavelmente negros.

O primeiro ganhador era Hilario Jose de Sant'Anna, de 24 anos, morador do Barbalho. O segundo foi Antonio Geraldo Gomes, de 32 anos e morador dos CurraisVelhos. Os outros dois eram Severiano Ferreira de Lima, de 28 anos, nascido em Cachoeira, e Adão de Sá Barreto, de 34 anos, ambos residentes na Rua Nova do Silva. Um dado importante foi trazido pelo professor Antonio José de Moraes, ao informar quais alunos 
chegaram à aula pública noturna com noções de leitura, somando seis em um universo de 24 discentes. Somente um deles era ganhador. Os demais eram: um alfaiate, um estivador, dois criados e um aguadeiro. Interessante reflexão sobre os meios de acesso a essa aprendizagem de leitura tomou parte deste trabalho e ficará para pesquisas vindouras.

Não podemos desconsiderar os diferentes exemplos de sujeitos negros e mestiços ${ }^{12}$ que conseguiram ultrapassar barreiras e obter mobilidade social dentro de uma sociedade marcada pela escravidão e a exclusão da população de cor. Nas pesquisas de Heloisa Villela (2012, p. 153) encontramos uma “(...) considerável presença de professores negros e mestiços que atuavam nas escolas da Corte e da província do Rio de Janeiro." Contudo, não somente na Corte existiam casos de professores negros, mas também na Bahia, Minas Gerais, São Paulo, Mato Grosso, Pernambuco, entre outras regiões do país.

Podemos citar, no caso da Bahia, o professor Cincinato Franca ${ }^{13}$, que era negro, proveniente das classes pobres, ativista defensor da abolição e da educação (CAVALCANTE, 2015). Segundo Maria Conceição Costa e Silva (1997, p. 109), esse professor criou, no ano de 1888, uma "escola gratuita para ingênuos e libertos", em Cachoeira, sua cidade natal. Essas características o fizeram ser muito bem quisto na região da Penha, onde ensinava e também morava desde 1891, quando fora transferido para a cidade do Salvador, "promovido por mérito em ato proposto e assinado por Sátiro Dias" (SILVA; 1997, p. 190). Este docente se constituiu em um agente de imensa importância na escolarização pública primária da Bahia no período prévio à abolição e no pós-abolição, com atuação até a década de 1920.

Um fator que nos preocupou nesta pesquisa foi o impacto do processo de escolarização sobre a população soteropolitana, justamente nesse contexto marcado pela emancipação dos escravos e pela virada nos rumos da política com a proclamação da República. Ganha cenário cada vez maior em nível nacional compreender como a instrução pública primária ou outros tipos de educação (formais ou informais) influenciaram e foram influenciados- considerando sempre a relação dialética histórica- nas diferentes sociedades no pós-abolição (Schueler, 2011; Barros, 2005).

\section{Escolarização na Salvador do final do século XIX e começo do século XX.}

Dois dos ofícios encontrados nos permitem fazer um paralelo, limitado às fontes disponíveis entre a década de 1870 e o ano de 1897, em alguns aspectos que trabalharemos a seguir. Com a ajuda da Relação das escholas municipaes da capital com a declaração dos Logares em que se acham colocadas procedido em $1870,{ }^{14}$ obtivemos diferentes informações sobre os distritos que importam nesta pesquisa. Tais distritos eram distribuídos entre duas circunscripções ${ }^{15}$ e as escolas, nessas circunscrições, estavam divididas entre masculinas, femininas e mistas.

Dos distritos trabalhados aqui (Sé, Conceição da Praia, Rua do Passo e Santo Antônio além do Carmo), o do Santo Antônio além do Carmo foi o que possuiu a maior quantidade de escolas no ano de 1870. A hipótese é a de que esse número elevado de escolas no distrito foi decorrente do grande contingente populacional pertencente às camadas menos abastadas, incluindo pretos e pardos, livres e libertos. Tal conjunto demográfico é apontado, por exemplo, nas pesquisas de Wlamyra Albuquerque (2009). Do mesmo modo, estudos sobre diferentes partes do Brasil também demonstram a intenção do governo republicano, instaurado em 1889, em escolarizar a população mais carente, entre a qual estavam pretos e pardos, livres e libertos. São exemplos disso as pesquisas de Mauricéia Ananias (2000), Ione Sousa (2006), Surya Barros (2005), Irma Rizzini e Alessandra Schueler (2014). 
A tabela 01 nos demonstra algumas características interessantes do ano de 1870. Percebemos que o distrito com o maior número de escolas e com a única que era mista, atendendo tanto meninos quanto meninas, foi o do Santo Antônio além do Carmo. Acreditamos que, junto ao distrito da Penha, o distrito do Santo Antônio além do Carmo se caracterizou, durante o pós-abolição, como um dos que possuía maior concentração de cidadãos pobres, ou de poucas posses, e de cor da pele preta ou parda. O alto número de escolas, quando comparado aos outros distritos, seria um indício que vem para corroborar essa hipótese, junto a pesquisas como a de Wlamyra Albuquerque (2009). Outro fator que pode ser percebido no quadro é a presença de uma escola mista, tipo de ensino que começou a ser utilizado na cidade do Salvador durante o final do Império, segundo o qual meninos e meninas estudavam no mesmo espaço físico.

Tabela 01

Relação das escolas e gênero do ano de 1870.

\begin{tabular}{lcccc}
\hline Distritos & Masculina & Feminina & Mista & Total de escolas \\
\hline Sé & 03 & 02 & 00 & $\mathbf{0 5}$ \\
Conceição da Praia & 01 & 01 & 00 & $\mathbf{0 2}$ \\
Rua do Passo & 02 & 02 & 00 & $\mathbf{0 4}$ \\
Penha & 02 & 02 & 00 & $\mathbf{0 4}$ \\
Santo Antônio além do Carmo & 03 & 04 & 01 & $\mathbf{0 8}$ \\
\hline \hline Total & $\mathbf{1 1}$ & $\mathbf{1 1}$ & $\mathbf{0 1}$ & $\mathbf{2 3}$ \\
\hline
\end{tabular}

Fonte: APMS. Relação das escholas municipaes da capital com a declaração dos Logares em que se acham colocadas procedido em 1870. Ver: Fundo: Intendência Municipal, Seção: Ensino Municipal; Diretoria de Ensino Municipal: Ofícios e Requerimentos caixa 20.

No mesmo relatório do delegado Araponga, encontramos outro mapa ${ }^{16}$, no qual constavam o número de escolas e seus professores regentes, o número de alunos e as condições das salas de aula, além de algumas observações. Em junho de 1896, a $2^{\text {a }}$ circunscrição registrou 31 escolas, divididas em seis distritos, e nos quatro que são de nosso interesse o total foi de 22 escolas públicas primárias. O distrito da Conceição da Praia apareceu na relação com quatro escolas, duas femininas e duas masculinas, e 68 alunos matriculados, sendo que 46 freqüentavam as aulas. Desse total, havia 35 meninos matriculados (26 com freqüência) e 33 meninas matriculadas (20 freqüentando). Dessas escolas, duas estariam com suas salas de aula em condições de "acanhada" e "regular". As outras duas, que não apareceram na relação anterior pelo fato de não terem sido criadas pelo estado e sim pela municipalidade, constavam na relação com salas de aulas tidas como "boa" e "muito boa" e foram citadas como "ultimamente criadas".

Já o distrito da Rua do Passo possuía também quatro escolas, duas femininas e duas masculinas, com um total de 205 alunos matriculados, e 166 de freqüência, em três delas. Uma das escolas apareceu como recentemente criada em 1896 e seu professor regente teria assumido no dia anterior ao da elaboração do mapa, 19 de junho, motivo pelo qual não constavam alunos matriculados. Eram 38 meninos e 167 meninas matriculados, 22 meninos e 124 meninas que freqüentavam as aulas, em salas que tinham condições "boa" e "regular".

O distrito do Santo Antônio além do Carmo apareceu com o maior número de escolas entre os aqui destacados, totalizando nove, das quais três eram masculinas, quatro, femininas e duas, mistas. Somava 400 alunos matriculados e 263 de freqüência, divididos em 151 meninos matriculados nas escolas masculinas, 180 meninas nas escolas femininas e 69 meninos e meninas nas mistas. A primeira escola citada neste distrito, do professor Raymundo Gomes, registrava uma sala de aula em condição "muito boa". Outras duas escolas constavam como possuindo salas "regulares", outras duas apresentavam salas "boas" e as duas mistas tinham salas "acanhadas". 
Na tabela 02, sintetizamos as informações referentes ao ano de 1896, e ficou claro o considerável aumento no número de escolas quando comparado ao da tabela 01 , que contém os dados de 1870. A quantidade de escolas subiu de 23, nos cinco distritos em questão, para 27 , contando com o distrito da Sé que não foi incluído no quadro abaixo, pois pertencia à $1^{\text {a }}$ circunscrição. Um aumento de quatro escolas corrobora nossa hipótese de que houve uma ampliação na escolarização soteropolitana durante o período do pós-abolição, impulsionada não somente pela legislação, mas pela preocupação em "civilizar" a população pobre, em sua maioria negra, nos moldes republicanos.

Tabela 02

Mapa das escolas da $2^{\text {a }}$ circunscrição do ano de 1896.

\begin{tabular}{|c|c|c|c|c|c|c|c|c|c|}
\hline Distritos & $\begin{array}{l}\text { Escolas } \\
\text { Masc }\end{array}$ & $\begin{array}{l}\text { Escolas } \\
\text { Fem }\end{array}$ & $\begin{array}{l}\text { Escolas } \\
\text { Mistas }\end{array}$ & Total & $\begin{array}{l}\text { Mat } \\
\text { masc }\end{array}$ & $\begin{array}{l}\text { Mat } \\
\text { fem }\end{array}$ & $\begin{array}{l}\text { Freq } \\
\text { masc }\end{array}$ & $\begin{array}{l}\text { Freq } \\
\text { fem }\end{array}$ & Salas de aula \\
\hline $\begin{array}{l}\text { Conceição } \\
\text { da Praia }\end{array}$ & 01 & 01 & 00 & 04 & 35 & 33 & 26 & 20 & 1 acanhada, 1 regular. \\
\hline Rua do Passo & 02 & 02 & 00 & 04 & 38 & 167 & 22 & 124 & 2 boas, 2 regulares. \\
\hline $\begin{array}{l}\text { Santo Antônio } \\
\text { além do Carmo }\end{array}$ & 03 & 04 & $01 *$ & 08 & 151 & 180 & 110 & 112 & $\begin{array}{c}1 \text { muito boa, } 2 \text { boas, } 2 \\
\text { regulares, } 2 \text { acanhadas. }\end{array}$ \\
\hline Penha & 02 & 02 & $01 *$ & 05 & 106 & 100 & 43 & 53 & $\begin{array}{c}3 \text { acanhadas, } 1 \text { regular, } 1 \\
\text { boa. }\end{array}$ \\
\hline Total & 09 & 10 & $\overline{03}$ & 19 & 330 & 480 & 201 & 309 & $\begin{array}{c}6 \text { acanhadas, } 6 \text { regulares, } \\
6 \text { boas, } 2 \text { muito boas. }\end{array}$ \\
\hline
\end{tabular}

Fonte: APMS. Mappa das escholas que se achão funcionando nos seis distritos urbanos da $2^{a}$ Circunscripção Litteraria do Municipio da Capital da Bahia. Elaborado pelo Delegado Escolar João Theodoro Araponga, 20 de junho de 1896. Ver: Fundo: Intendência Municipal, Seção: Ensino Municipal; Diretoria de Ensino Municipal: Ofícios e Requerimentos, caixa 01.*As escolas mistas não constam na tabela, nos dados de matrícula e frequiência. Seguem as informações: Santo Antônio além do Carmo: matrícula de 69 alunos e freqüência de 32 alunos entre meninos e meninas. Penha: matrícula de 16 alunos e freqüência de 11 alunos.

Esse grupo populacional, como já sabemos, não era passivo receptor dos acontecimentos vindos "de cima", mas sim atuante em sua agência histórica, utilizando a instrução pública primária como um dos mecanismos para alcançar uma ascensão social, ou até mesmo para tentar influenciar os rumos do país. A partir de 1881, após a aprovação da Lei Saraiva, que estabelecia um nível mínimo de escolarização (saber ler e escrever) para votar, o número de eleitores diminuiu bastante. Em 1872, o total da população que poderia participar do sufrágio girava em torno de 10\%, enquanto em 1886, após a Lei Saraiva, esse número caiu para 0,8\%. (CASTELUCCI, 2008, p. 27). A escolarização, por menor que fosse, poderia fazer a diferença para os habitantes da cidade do Salvador no pós-abolição, onde a rede de escolas públicas primárias crescia e tentava se organizar.

As escolas femininas passaram a ser maioria e o número de alunas que estavam matriculadas e que freqüentavam as aulas continuou sendo muito superior ao dos alunos, quando comparado ao ano de 1870. O distrito do Santo Antônio além do Carmo continuou sendo a região com maior número de escolas e de alunos, e a Penha se manteve em segundo lugar no número de matrículas, porém em relação à freqüência o distrito da Rua do Passo ficou em segundo lugar. Nessa tabela, podemos visualizar também a descrição das salas de aula, que em sua maioria eram acanhadas ou regulares.

Quanto às escolas que foram registradas na documentação como "ultimamente criadas", encontramos na Conceição da Praia uma masculina e uma feminina. Outras duas apareceram com a mesma observação no distrito do Pilar, que não entra nesta pesquisa, sendo uma feminina e uma mista. Por sua vez, tínhamos uma escola mista "ultimamente criada" no distrito do Santo Antônio além do Carmo, e mais uma escola mista na mesma situação no distrito da Penha. Esses dados nos fazem inferir que houve um crescimento no 
número de escolas quando se municipalizou o ensino público primário, pelo menos nessa circunscrição literária. Nos impressionou também a quantidade de escolas mistas "ultimamente criadas", num total de três, o que ajudou a corroborar o aumento no número de escolas voltadas para o ensino misto em 1896, como podemos visualizar na tabela 03.

Esse crescimento caminhou em conjunto com a tentativa de organizar a instrução pública primária, seguindo exemplos de outros países, como Estados Unidos e França. As instituições mistas facilitavam o acesso dos alunos à escola, tendo em vista que irmãos ou irmãs mais velhos poderiam levar seus irmãos para a mesma escola que freqüentavam. Por outro lado, essa categoria de escola estava ligada aos ideais de modernidade, que eram propagados pelo regime republicano como o caminho para alcançar a tão desejada civilização.

Tabela 03

Relação das escolas "ultimamente criadas", após a municipalização do Ensino Público Primário, no ano de 1896.

\begin{tabular}{lcccc}
\hline Distritos & $\begin{array}{c}\text { Escolas } \\
\text { Masc. }\end{array}$ & $\begin{array}{c}\text { Escolas } \\
\text { Fem. }\end{array}$ & $\begin{array}{c}\text { Escolas } \\
\text { Mistas }\end{array}$ & Total \\
\hline Conceição da Praia & 01 & 01 & 00 & 02 \\
Pilar* & 00 & 01 & 01 & 02 \\
Santo Antônio além do Carmo & 00 & 00 & 01 & 01 \\
Penha & 00 & 00 & 01 & 01 \\
\hline \hline Total & $\mathbf{0 1}$ & $\mathbf{0 2}$ & $\mathbf{0 3}$ & $\mathbf{0 6}$ \\
\hline
\end{tabular}

Fonte: APMS. Mappa das escholas que se achão funcionando nos seis distritos urbanos da $2^{a}$ CircunscripçãoLitteraria do Municipio da Capital da Bahia. Elaborado pelo Delegado Escolar João Theodoro Araponga, 20 de junho de 1896. Ver: Fundo: Intendência Municipal, Seção: Ensino Municipal; Diretoria de Ensino Municipal: Ofícios e Requerimentos, caixa 01.*Apesar deste distrito não estar em nossa pesquisa, ele constou registrado na documentação dentre os que tiveram escolas "ultimamente criadas" após a municipalização do ensino primário.

Entre a documentação localizada também encontramos outro ofício que continha o Mappa do Professorado Municipal em exercício com declaração das cadeiras providas, sua especie, matricula e frequencia de alumnos e dos logares em que funcionam as mesmas em relação ao anno de 1897, referente à $1^{a}$ e $2^{a}$ Circusncripção. A localização das escolas permaneceu a mesma que constava na relação produzida em 1870. Interessante mencionar o fato de o professor da $1^{\text {a }}$ cadeira masculina da Sé ter sido Diogo Vallasques, regente concursado em 1892, teve destaque na Revista do Ensino Primário (publicada entre os anos de 1892 e 1893) por ter escrito artigos que denunciavam a precariedade das escolas públicas primárias a cargo do município. As fontes apontaram que, apesar de suas duras críticas, permaneceu lecionando e apareceu novamente na documentação do ano de 1897.

$\mathrm{Na}$ tabela 04, estão registradas informações mais detalhadas sobre o ano de 1897. O número de escolas mistas, nesta tabela, aumentou de 1 para 2 em relação ao ano de 1870 . Este fato nos intrigou, tendo em vista que em outro documento, o mapa das escolas do ano de 1896, o número de escolas mistas aumentara para 3 nos distritos aqui pesquisados, como já foi citado. O total de escolas teve um aumento considerável comparando as tabelas acima. Na tabela 01 (1870) encontramos um total de 23 escolas, enquanto na tabela 02 (1896) esse número aumentou para 25 escolas, contando com aquelas localizadas no distrito da Sé. E na tabela 04 percebemos que para o ano de 1897, o total permaneceu em 24 escolas públicas primárias nos distritos aqui pesquisados. Em relação à quantidade de estudantes, o número de meninas foi superior ao de meninos. O distrito com maior número de alunos e alunas foi o do Santo Antônio além do Carmo, seguido pelo da Penha e, em terceiro lugar, o da Sé - 
primeiro distrito da cidade, com localização central. Quanto ao número de alunos prontos, percebemos que, apesar de poucos, o distrito da Penha se destacou.

Tabela 04

Relação do professorado, matrícula e frequência dos alunos no ano de 1897 . $1^{\mathrm{a}}$ e $2^{\mathrm{a}}$ circunscrições.

\begin{tabular}{lcccccccccc}
\hline Distritos & $\begin{array}{l}\text { Escolas } \\
\text { Masc }\end{array}$ & $\begin{array}{l}\text { Escolas } \\
\text { Fem }\end{array}$ & $\begin{array}{l}\text { Escolas } \\
\text { Mistas }\end{array}$ & Total & Matmasc & $\begin{array}{l}\text { Mat } \\
\text { fem }\end{array}$ & $\begin{array}{l}\text { Freq } \\
\text { masc }\end{array}$ & $\begin{array}{l}\text { Freq } \\
\text { fem }\end{array}$ & $\begin{array}{l}\text { Alunos } \\
\text { prontos }\end{array}$ & $\begin{array}{l}\text { Alunas } \\
\text { prontas }\end{array}$ \\
\hline Sé & 03 & 02 & 0 & $\mathbf{0 5}$ & $\mathbf{9 3}$ & $\mathbf{1 5 6}$ & $\mathbf{6 4}$ & $\mathbf{1 2 1}$ & $\mathbf{1}$ & $\mathbf{3}$ \\
$\begin{array}{l}\text { Conceição da Praia } \\
\text { Rua do Passo }\end{array}$ & 01 & 01 & 0 & $\mathbf{0 2}$ & $\mathbf{4 5}$ & $\mathbf{4 9}$ & $\mathbf{3 4}$ & $\mathbf{3 0}$ & $\mathbf{0}$ & $\mathbf{0}$ \\
$\begin{array}{l}\text { Santo Antônio } \\
\text { além do Carmo }\end{array}$ & 02 & 02 & 0 & $\mathbf{0 4}$ & $\mathbf{7 9}$ & $\mathbf{1 8 2}$ & $\mathbf{4 1}$ & $\mathbf{1 1 1}$ & $\mathbf{0}$ & $\mathbf{0}$ \\
Penha & 03 & 04 & $1 *$ & $\mathbf{0 8}$ & $\mathbf{2 7 8}$ & $\mathbf{2 4 8}$ & $\mathbf{1 5 1}$ & $\mathbf{1 7 1}$ & $\mathbf{0}$ & $\mathbf{0}$ \\
\hline Total & 02 & 02 & $1 *$ & $\mathbf{0 5}$ & $\mathbf{1 5 5}$ & $\mathbf{1 3 5}$ & $\mathbf{1 0 4}$ & $\mathbf{9 3}$ & $\mathbf{9}$ & $\mathbf{4}$ \\
\hline
\end{tabular}

Fonte: APMS. Municipio da Capital do Estado da Bahia: Mappa do professorado municipal em exercício para o ano de 1897, $1^{a}$ circunscripção. Ver: Fundo: Intendência Municipal, Seção: Ensino MunicipalDiretoria de Ensino Municipal: Ofícios e Requerimentos caixa 20. *A escola mista do Santo Antônioalém do Carmo não consta na tabela nos dados de matrícula e frequência. Seguem as informações: matrícula de 60 alunos e frequência de 24 alunos entre meninos e meninas. Não encontramos os dados relativos à escola mista da Penha.

O último relatório aqui trabalhado foi o Relatorio enviado ao Conselho Municipal pelo Professor Prisciliano José Leal - delegado interino da $2^{a}$ Circunscripção escolar ${ }^{17}$, de julho de 1902, relativo ao ensino primário. Nele encontramos, além do número de escolas por distrito, a situação geral da escolarização pública primária na $2^{\mathrm{a}}$ circunscrição da cidade do Salvador. Sintetizamos as informações sobre a quantidade de escolas na tabela 05, na qual podemos visualizar a ampliação do número de escolas primárias em quase todos os distritos. Estes dados revelaram, primeiramente, a ampliação do número de escolas nos distritos pesquisados da $2^{a}$ circunscrição escolar da cidade do Salvador, no começo do século XX. Para além disso, os números também mostraram que, em 1902, desapareceram as escolas mistas, enquanto as escolas femininas aumentaram consideravelmente em comparação com os dados de 1870 ou com os do mapa das escolas de 1896 e 1897, que já foram trabalhados aqui.

Tabela 05

Relação das escolas e gênero, da $2^{a}$ circunscrição escolar de Salvador, do ano de 1902.

\begin{tabular}{lcccc}
\hline Distritos & Masculina & Feminina & Mista & Total de escolas \\
\hline Conceição da Praia & 01 & 02 & 00 & $\mathbf{0 3}$ \\
Rua do Passo & 02 & 04 & 00 & $\mathbf{0 6}$ \\
Penha & 03 & 04 & 00 & $\mathbf{0 7}$ \\
Santo Antônio Além do Carmo & 04 & 06 & 00 & $\mathbf{1 0}$ \\
\hline \hline Total & $\mathbf{1 0}$ & $\mathbf{1 6}$ & $\mathbf{0 0}$ \\
\hline Fonte: APMS. Relatorio enviado ao Conselho Municipal pelo Professor Prisciliano José Leal - Delegado \\
interino da 2 ${ }^{a}$ Circunscripção escolar, relativamente ao ensino primário durante o 1 ${ }^{\boldsymbol{0}}$ do corrente anno. Bahia, \\
Julho de 1902. Ver: Fundo: Intendência Municipal, Seção: Ensino Municipal; Diretoria de Ensino Municipal: \\
Processos, caixa 03.
\end{tabular}

De 1870 a 1902, os registros demonstraram um enorme crescimento no número de escolas, passando de 23 para 31 instituições públicas primárias, caso inserimos a quantidade de 5 escolas correspondentes ao distrito da Sé. E este número ainda pode ser maior, pois não conseguimos obter informações sobre o número de escolas ali existentes para o ano de 1902, que poderia, também, ter sofrido um aumento. Analisando somente os números da tabela 05 , as escolas masculinas aumentaram de 8 para 10 e as femininas, que já eram maioria em 
1870, passaram de 09 para 16 em 1902. As mistas, que eram apenas 1 em 1870, sofreram um considerável aumento no final do século XIX, e deixaram de existir no começo da década de 1900. O que impressionou nesses dados foi o número de escolas femininas, que cresceu vertiginosamente, pulando de 08 em 1870 para 16 escolas primárias em 1902. Isso ajuda a comprovar nossa hipótese de que o gênero feminino esteve mais presente dentre os alunos das escolas pública primárias, do começo da República no universo aqui pesquisado.

\section{A cultura escolar por meio de alumnos promptos, matrículas e freqüência.}

Começamos esta análise por um relatório extenso, de autoria do delegado escolar professor João Araponga ${ }^{18}$, no qual foi descrita a passagem da responsabilidade pelo ensino público primário do estado para o Município. Segundo o delegado, havia 25 escolas nos seis distritos urbanos da $2^{a}$ circunscrição escolar, as quais passaram da administração estadual para a municipal. Ele relatou também que a mobília dessas escolas estaria quase toda incompleta e em mau estado.

Encontramos documentação na qual consta a quantidade de alunos e/ou alunas considerados formados no ensino primário para os distritos da Rua do Passo, no Santo Antonio além do Carmo, na Conceição da Praia e na Penha. Os chamados "alumnos promptos" encontrados nesse documento ${ }^{19}$, somam um total de 57 crianças, um número muito maior do que o anteriormente visto. Quanto ao gênero, foram registrados 27 meninos e 30 meninas. Esses dados nos trazem alguns questionamentos, em relação, por exemplo, à quantidade total de alunos e alunas formados no final de um ano, 57 neste caso.

Seria realmente um número abaixo do esperado, levando em consideração que essa soma poderia corresponder a somente uma das várias escolas do município? A outra questão está relacionada à grande diferença na quantidade de alunos formados entre o distrito da Penha e os demais pesquisados. Porque teria esse distrito se destacado tanto na formação de alunos? Utilizaria métodos diferenciados dos outros? Sabemos que, em boa parte, esse número elevado se deveu ao trabalho do professor Cincinato Franca.

Tabela 06

Relação dos alunos prontos divididos por professores e gênero (sem data e sem assinatura).

\begin{tabular}{|c|c|c|c|c|}
\hline Distritos & Professores & $\begin{array}{l}\text { Alunos } \\
\text { prontos } \\
\end{array}$ & $\begin{array}{l}\text { Alunas } \\
\text { prontas }\end{array}$ & $\begin{array}{l}\text { Total de } \\
\text { alun@s }\end{array}$ \\
\hline Rua do Passo & João Luiz & 03 & 0 & 03 \\
\hline Rua do Passo & João Ayres da Silva & 01 & 0 & 01 \\
\hline Rua do Passo & Hermelinda dos Sanctos & 00 & 02 & 02 \\
\hline Rua do Passo & AmaliaBahiense & 00 & 02 & 02 \\
\hline \multirow[t]{2}{*}{ Rua do Passo } & Corinthia da Fonseca & 00 & 02 & 02 \\
\hline & Total & 04 & 06 & 10 \\
\hline Santo Antônio & Martins de Freitas & 02 & 00 & 02 \\
\hline Santo Antônio & Maria Clementina Rego & 00 & 02 & 02 \\
\hline Santo Antônio & Virginia de Lima & 00 & 02 & 02 \\
\hline \multirow{2}{*}{ Santo Antônio } & Adélia Bittencourt & 00 & 03 & 03 \\
\hline & Total & 02 & 07 & 09 \\
\hline \multirow[t]{2}{*}{ Conceição da Praia } & Maria Olympia da Silva & 00 & 01 & 01 \\
\hline & Total & 00 & 01 & 01 \\
\hline Penha & Joaquim Mamede dos Santos & 08 & 00 & 08 \\
\hline Penha & Cincinato Franca & 13 & 00 & 13 \\
\hline Penha & Joanna Freire de Mello & 00 & 01 & 01 \\
\hline Penha & Maria Ambrosina Vaz Ferreira & 00 & 08 & 08 \\
\hline \multirow[t]{2}{*}{ Penha } & Ana Pereira dos Santos & 00 & 07 & 07 \\
\hline & Total & 21 & 16 & 37 \\
\hline Total & & 27 & 30 & 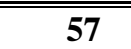 \\
\hline
\end{tabular}


Fonte: APMS. Relação dos alumnos promctos das escolas da $2^{a}$ Circunscripção, sem data e sem assinatura. Acreditamos que seja no nosso recorte temporário, pois estava junto à outra documentação pertencente aos anos entre 1896 e 1900, além de constarem somente os distritos que existem no recorte em questão, e os nomes de alguns professores serem os mesmos vistos em outros documentos do contexto trabalhado. Ver: Fundo: Intendência Municipal, Seção: Ensino Municipal; Diretoria de Ensino Municipal: Ofícios e Requerimentos caixa 01 .

$\mathrm{Na}$ tabela 06, vemos o total de alunos prontos por professor, em cada um dos distritos em análise. As meninas foram maioria, mas a diferença foi pouca: três alunas prontas a mais do que os alunos. Isto condiz com a maior quantidade de meninas no total de estudantes que encontramos matriculados no ano de 1897. O distrito da Penha se destacou, mais uma vez, como a região com o maior número de alunos prontos, e o professor Cincinato Franca novamente veio à tona como o docente com o maior número de discentes formados. A quantidade de alunas e alunos prontos no distrito da Penha foi superior à do segundo colocado, o distrito da Rua do Passo, em 27 alunos. Outra diferença importante foi a estabelecida entre este professor e os segundos colocados nessa relação, os professores Joaquim Mamede e Maria Ambrosina Vaz Ferreira, ambos regentes da Penha. Cincinato formou cinco estudantes a mais, enquanto os demais docentes, daí para baixo, tiveram números mais próximos. Esse aspecto se soma aos outros já apresentados aqui para dimensionar a importância do distrito da Penha no ensino público primário soteropolitano.

Sobre as "Escolas que deram alumnos a exames finaes" 20 , temos também informações sobre o ano de 1902, nas quais constam todos os distritos abordados neste capítulo. A Sé apareceu com um total de 12 alunos divididos entre os quatro professores do distrito e a Conceição da Praia registrou somente uma aluna, da professora D. Jesuina de Oliveira. O distrito da Rua do Passo conseguiu colocar 22 alunos para realizar os exames finais, tendo destaque o professor Lucio Casemiro Santos e a professora Maria Augusta Oliveira, ambos com um total de oito alunos cada. O distrito do Santo Antônio além do Carmo, apesar de ser um local com um número alto de escolas primárias, constou na relação com apenas cinco alunas divididas em duas escolas, ambas femininas.

Novamente o distrito da Penha foi o de maior expressão entre todos os pesquisados, com a mais elevada quantidade de alunos a ter respondido aos exames finais: um total de 25 meninos e meninas. A escola que apareceu na relação com o número mais elevado, entre os distritos que nos interessam aqui e entre todos os outros da cidade, foi novamente a regida pelo professor Cincinato Franca, com um total de 12 alunos. Na seqüência, estava a escola do professor Joaquim Mamede, que somou seis alunos, a metade de seu companheiro de profissão. Esses resultados deviam estar interligados com a agência do professor Cincinato e seus interesses em modificar a condição social do seu alunado, que muito provavelmente era formado por negros de pequenas posses.

Para termos uma noção sobre o número médio de alunos e alunas que freqüentavam as aulas e daqueles que somente estavam matriculados, mas não freqüentavam as aulas, podemos utilizar os mapas escolares, assim como os relatórios elaborados pelos delegados escolares. Os primeiros nos mostraram a versão produzida pelos professores e os segundos descreveram as visitas da inspeção escolar às escolas, incluindo os números de alunos matriculados e que estavam presentes nas datas das visitas. João Araponga visitou diversas escolas nos anos de 1896 e 1897.

Entre as escolas visitadas, encontramos a " 1 a Aula Municipal do Distrito de Santo Antonio [além do Carmo]",21, nessa época regida pelo nosso já conhecido professor Raymundo Cardoso Gomes. O relatório sobre as visitas do delegado escolar foi dividido, no quadro abaixo, por meses, e mostrou um crescimento no número de matrículas e na frequiência dos alunos com o passar do tempo. Por outro lado, percebemos que cresceu 
também a diferença entre o número de alunos matriculados e a quantidade de alunos presentes nos dias das visitas, como podemos visualizar na tabela 07, abaixo.

Tabela 07

Matrícula e freqüência dos alunos da " $1^{a}$ Aula Municipal do Distrito de Santo Antônio" regida por Raymundo Gomes nos anos de 1896 e 1897, por meio das visitas do delegado escolar.

\begin{tabular}{lcc}
\hline Meses/Ano & $\begin{array}{c}\text { Alunos } \\
\text { matriculados }\end{array}$ & Freqüência de alunos \\
\hline Maio/1896 & 20 & 20 \\
Junho/1896 & 33 & 20 \\
Julho/1896 & 35 & 18 \\
Agosto/1896 & 51 & 38 \\
Fevereiro/1897 & 38 & 38 \\
Março/1897 & 55 & 44 \\
Maio/1897 & 70 & 60 \\
Julho/1897 & 80 & 55 \\
Setembro/1897 & 88 & 60 \\
Outubro/1897 & 90 & 45 \\
\hline \hline Matrícula e freqüência média & $\mathbf{5 6}$ & $\mathbf{4 0}$ \\
\hline Fonte: APMS. ${ }^{a}$ Aula Municipal do Distrito de Santo Antonio. Relatório de visitas do Delegado Escolar João \\
Theodoro Araponga, nos anos de 1896 e 1897. Ver: Fundo: Intendência Municipal, Seção: Ensino Municipal; \\
Diretoria de Ensino Municipal: Ofícios e Requerimentos, caixa 01.
\end{tabular}

Outra escola presente nos registros do delegado escolar foi a do sexo feminino da Conceição da Praia regida pela professora Candida Sampaio Batista, da qual foi possível analisar a frequiência dos alunos, pelo menos durante outubro de 1897. Dos 31 dias do mês, não houve um no qual a freqüência tenha sido completa, chegando, no máximo, a 45 alunas e, no mínimo, a 25 alunas, de um total de 60 matriculadas. A ausência dos estudantes nas escolas públicas primárias no período do pós-abolição foi um tema que preocupou autoridades baianas, como nos mostrou o delegado Araponga, em seu relatório do ano de 1896. Ele destacou esse assunto quando relatou ao intendente municipal lacunas relativas à obrigatoriedade do ensino primário.

A obrigatoriedade escolar é parte fundamental nesta análise, visto que a partir dela se estabeleceu uma tensão entre o poder público e a sociedade civil. Filhos ou filhas deveriam então ser mantidos nas escolas em vez de estarem ajudando os pais no trabalho, vadiando ou trabalhando em outros espaços públicos. Neste ponto, é fundamental perceber a importância da instrução pública primária para as classes menos abastadas e até onde essa instrução era necessária. Como o próprio delegado escolar expôs em seu relatório, meninos e meninas eram vistos atuando como vendedores ou cozinheiras nos comércios de suas mães, ou em vadiações diversas. Tal indício pode corroborar a hipótese de que, após aprenderem a ler e escrever, os meninos e meninas já começavam a trilhar os caminhos do mundo do trabalho. Por outro lado, percebemos também que a obrigatoriedade escolar surgiu tanto por vontade do governo quanto por necessidades sociais atreladas aos projetos políticos. Como aponta Diana Vidal (2013), quando nos debruçamos sobre o tema devemos considerar tanto os argumentos que defendem quanto os que atacam a obrigatoriedade escolar, no intuito de perceber as "representações sociais em luta" e "os possíveis construídos para a escola brasileira na negociação entre os grupos sociais." (VIDAL, 2013, pp. 11-12).

Apesar de a obrigatoriedade, a partir de 1890, ter compreendido as crianças entre $7 \mathrm{e}$ 13 anos de idade, os mappas de alumnos $^{22}$ das escolas públicas primárias da cidade do Salvador nos têm mostrado que havia o registro de meninos e meninas de até 5 anos. Também infere-se que era baixa a presença de alunos maiores de 12 anos nas escolas 
elementares. Uma questão interessante está relacionada ao número de faltas dos alunos, que em alguns casos ultrapassou a casa dos 100 dias por ano letivo.

$\mathrm{O}$ relatório do delegado escolar tornou-se muito importante ao ampliar a perspectiva sobre a questão da frequiência. Ele conseguiu fazer com que percebêssemos a preocupação com o baixo número de discentes e chamou a atenção, principalmente, pela explicação dada para esta freqüência reduzida, a qual foi diferenciada por gênero. A preocupação da autoridade escolar com a vadiagem dos meninos, representada pelo "maldito vicio do jogo" ou pela venda de "bilhetes da loteria", está de acordo com a preocupação das autoridades do Rio de Janeiro no final do Império - período próximo ao trabalhado aqui -, conforme relatado por Sidney Chalhoub (1996). As pesquisas de Walter Fraga Filho (1996 e 2004) e Wlamyra Albuquerque (2009) sobre o estado da Bahia, no final do período imperial, abolição e pós-abolição, também apontam essa mesma preocupação. Em relação às meninas, os dados apresentados pelo delegado Araponga confirmam o que as pesquisas de Alberto Heráclito Ferreira Filho (1998/99) e Mário Augusto da Silva Santos (2001) já demonstraram: a importância das mulheres no comércio de rua na Salvador da Primeira República.

Neste ponto, vamos um pouco além da perspectiva desses autores, pois percebemos a presença das filhas de quitandeiras, vendedoras e comerciantes nos negócios de suas mães ou responsáveis. Isso ajuda a explicar não só o porquê da baixa freqüência, principalmente quando os alunos ou alunas passam dos 10 anos de idade, mas também nos mostra um embate entre a cultura escolar e a cultura urbana na cidade do Salvador. Tal conflito se estabelece na medida em que as autoridades governamentais, representadas aqui pelo Município, passam a fazer da presença escolar algo obrigatório para a faixa etária entre 7 e 14 anos, como já foi relatado neste trabalho.

A cultura escolar se expressava através de suas instituições e demandava a permanência desses meninos e meninas na escola, durante cinco ou seis horas diárias. Já a cultura urbana se manifestava por meio dos responsáveis pelos alunos, exigindo a presença destes nos locais de trabalho. Tal imposição ia além da necessidade de aprender a prática laboral dos pais, se voltando também para o sustento da casa. Por outro lado, não podemos deixar de considerar que tanto a escola quanto a família, assim como outros espaços, são meios de socialização e se relacionam na cena urbana, como afirma Luciano Mendes de Faria Filho, onde se alternam hostilidade e apropriação em relação à escolarização e à cultura escolar. (FARIA FILHO, 2012, p. 34).

Quais seriam os interesses envolvidos na produção de documentos, levando em conta todas as dificuldades encontradas na instrução pública primária, nos quais os docentes descreveram que todos os seus alunos ou alunas obtiveram um procedimento de bom a ótimo? Com certeza buscava-se proteger a fonte de renda desses professores e professoras e um dos seus meios de se sustentar. Tais questionamentos nos fazem pôr em dúvida algumas das informações encontradas nos mapas escolares elaborados pelos professores públicos primários. Esses documentos eram formulados para atender a determinados interesses dos diferentes agentes sociais envolvidos no ensino público primário, como nos lembra Diana Vidal (2008). Nesta pesquisa, percebemos que atribuir a classificação "bom" ou "regular" aos alunos era uma prática muito comum entre o professorado público primário da capital baiana, e que esteve presente em todos os distritos aqui destacados.

A análise desse conjunto documental também nos faz refletir sobre a relação entre matrícula, freqüência escolar e faixa etária, principalmente quando comparamos os números ligados à freqüência e aqueles vinculados à idade dos alunos ou alunas. Independentemente do gênero, percebemos que foi majoritária a presença dos estudantes mais jovens. Quanto aos mais velhos, ainda que figurando nas listas de matrículas, a maioria quase não 
freqüentava as salas de aula, muito provavelmente para estar em outros espaços de socialização.

As escolas elementares identificadas possuíam em média 60 alunos e algumas daquelas com mais de 50 alunos registravam professores adjuntos, porém vale ressaltar que ainda há documentação a ser encontrada e analisada. Tampouco consta nos mapas o tipo de ensino primário de cada escola, tendo em vista que, em 1890, este nível de ensino estava dividido em ensino infantil, ensino primário e ensino primário superior. ${ }^{23} \mathrm{Já}$ entre 1895 e 1904, passou a ser segmentado em ensino infantil, elementar ou de $1^{\circ}$ gráoe complementar ou de $2^{o}$ gráo. ${ }^{24}$

\section{Por bem do nosso progresso litterario: a relação entre comunidade, famílias e a instrução pública primária.}

A relação entre famílias, professores e escolas não poderia deixar de estar presente, pelo menos em parte, nesta pesquisa. Entre a documentação, encontramos três ofícios que expressaram a opinião de diferentes setores da comunidade escolar sobre alguns integrantes do corpo docente municipal na virada do século. O professor Raymundo Cardoso Gomes apareceu citado em um abaixo assinado feito pelos seus próprios alunos. Seus pupilos solicitaram sua permanência na escola, visto que ele seria removido para o distrito de São Pedro. Em ofício ao "Illmo. e Ex. Senhor Dr. Intendente do Municipio desta Capital", os alunos escreveram:

Nós abaixo assignados alumnos da Escola Publica do sexo masculino da Freguesia de Sant'Antonio além do Carmo, vem respeitosamente pedir a V. Exe. que haja por bem do nosso progresso litterario de revogar o acto em que remove o Nosso Digno Mestre o Sñr. Raymundo Cardoso Gomes, desta cadeira para a de São Pedro (.... $)^{25}$ [grifos nossos].

No dia 10 de fevereiro de 1900 , um total de 25 alunos $^{26}$ da $1^{\text {a }}$ escola do sexo masculino do distrito do Santo Antônio além do Carmo solicitaram a revogação do ato que lhes tiraria seu professor. No ofício, os meninos escreveram de maneira muito clara, utilizando argumentos válidos e fazendo inclusive um apelo em relação ao seu progresso literário que, segundo eles, ficaria prejudicado com a saída do professor Raymundo Gomes. Este docente, que como já vimos era atuante e engajado, crítico consistente da situação da instrução pública primária, contava com o apoio de seus alunos para tentar continuar em sua escola. O documento pode ter sido elaborado pelos próprios estudantes ou pelo professor, e, neste caso, somente fora assinado pelos discentes. Provavelmente, Raymundo Gomes devia possuir interesses em permanecer no Santo Antônio além do Carmo, mas não temos como saber quais seriam esses interesses, se estariam voltados a ajudar os alunos mais carentes ou ligados a benefícios para o próprio professor. Somente a continuação desta pesquisa poderá elucidar mais detalhes.

Encontramos ainda um relato sobre outro docente que criticou o governo, no que tange à educação pública primária, na Revista do Ensino Primário nos anos de 1892 e 1893. O professor Thiotimo de Almeida também foi citado em um abaixo assinado, feito por pais e mães de seus alunos em 1900, mas por conta de desvios morais em sua conduta. Alguns moradores do distrito de Itapoan, talvez pais de estudantes da escola municipal do sexo masculino, elaboraram um abaixo assinado, contando com a participação de alguns agentes sociais de certo prestígio. Por acreditar que tal ofício seja importante para este contexto, achamos melhor reproduzi-lo, em parte: 
Nós abaixo assignados attestamos e juramos se preciso porque o professor Manoel Thiotimo de Almeida, continuamente se embriaga nesta freguesia e neste estado, provoca, insulta e injuria, ao [...] Governador do Estado, a Intendencia Municipal, e as auctoridades locais com os epitetos de ladrões, infames, falçarios e outros que a decencia nos faz calar; e por ser verdade passamos e assignamos sob juramento. Itapoan $1^{\circ}$ de Maio de 1900. (...)

Reconheço as firmas [...]

Brasil 15 de Maio de 1900

[Assinatura ilegível] ${ }^{27}$ [grifos nossos].

Interessante notar que participaram da lista desde subcomissários, passando por juízes de paz, até cidadãos comuns que se viam incomodados com os atos do docente. $\mathrm{Na}$ argumentação destes moradores, a representação social de um professor público primário teria que ser a de um cidadão exemplar, com a tarefa de civilizar a juventude e, assim, atender aos interesses da nação. A ação de Thiotimo, para eles, era vergonhosa e não condizia com o papel de um professor primário, o qual não deveria ficar se embriagando e insultando o governador do estado, a Intendência Municipal ou as autoridades locais.

O professor Thiotimo era, também, redator da Revista do Ensino Primário, na qual escreveu artigos denunciando a situação precária da instrução pública municipal. Ele também apareceu como docente do distrito de Itapoan na documentação de 1897. No episódio que motivou o abaixo assinado, seus textos com palavras rebuscadas, escritos de maneira impecável no começo da década de 1890, deram lugar, em 1900, a um desabafo contra as autoridades encarregadas de administrar o ensino municipal.

Supomos que embates e tensões estavam envolvidos na práxis diária desse professor público primário. No entanto, tais conflitos eram comuns entre os agentes sociais da escolarização, não tendo relação com a conduta moral de Thiotimo ou com seu julgamento a respeito da instrução pública. O importante aqui é atentar para a manipulação do argumento de boa conduta e moral que o professor público deveria possuir para que pudesse ensinar a seus alunos. Infelizmente, não encontramos o desfecho dessa experiência histórica na documentação, e sendo assim não sabemos quais medidas foram ou não foram tomadas contra o professor Thiotimo.

É fundamental também observar que o ensino público primário, ou a educação de uma maneira geral, assume neste ponto um papel relevante. Esses dois últimos casos, do professor Raymundo Gomes e do professor Thiotimo de Almeida, nos demonstram como a comunidade que era envolvida no processo de escolarização estava atuante enquanto agentes sociais. Por um lado, os alunos, ao terem redigido ou assinado um documento que solicitava a permanência do professor Raymundo. Por outro, os pais ou responsáveis que oficializaram uma reclamação contundente com denúncias claras sobre o professor Thiotimo. Damos destaque aqui à participação de diferentes agentes, provenientes de lugares sociais ${ }^{28}$ distintos e que, ao mesmo tempo, carregavam capitais culturais, sociais e econômicos ${ }^{29}$ diversos.

A posição da família perante a educação dos filhos ganhou destaque aqui, pois é de suma importância analisar se, no contexto em questão, as famílias das classes menos abastadas viam a instrução pública primária de acordo com sua avaliação sobre as "chances objetivas de futuro" para seus filhos (PAIXÃO; 2006, p. 59). Outro fator relevante está relacionado ao lugar que a instituição escolar ocupava na "hierarquia social", envolvendo questões materiais e simbólicas (PAIXÃO; 2006, p. 59).

As relações entre as famílias populares ${ }^{30}$ e a escolarização estão inseridas em uma dialética envolvendo "instituições de socialização ou enquadramento e membros das classes 
populares" (THIN; 2006, p. 18). Não podemos esquecer, no entanto, que a especificidade de tais relações está atrelada a um processo que possui suas "próprias características" e confronta "práticas socializadoras divergentes" (THIN; 2006, p. 18). Portanto, estudar o processo de escolarização, no contexto em questão ou em qualquer outro, demanda que se interrogue as fontes sobre a forma como as "lógicas escolares" e o "modo escolar de socialização" se relacionam com outras "lógicas socializadoras" (THIN, 2006).

\subsection{A agência dos professores públicos primários e dos delegados escolares: tensões e embates.}

Entre solicitações de afastamento por doença, pedidos de posse de cadeiras, requisição de materiais, asseio ou reparos e ainda questões relacionadas à casa ou ao prédio que abrigava as escolas públicas primárias, encontramos dois ofícios que chamaram a atenção. O primeiro deles é o relatório ${ }^{31}$ do delegado escolar João Theodoro Araponga, escrito em 1897, que descreveu o estado das escolas e sugeriu o que deveria ser feito para melhorar a condição do ensino público primário. O texto começava relatando o quão "é lastimavel este estado de cousas tanto mais quanto as penurias das finanças municipaes (...) ${ }^{\prime 32}$, citava as dificuldades encontradas para manter as escolas e em seguida listava o que, segundo ele, tornava-se necessário para mudar tal estado lamentável.

O primeiro item da lista foi uma sugestão feita ao intendente municipal para que este autorizasse Araponga a fazer um remanejamento de mobília entre algumas escolas da circunscrição. De acordo com o delegado, “(...) removendo as peças que demais eistão em algumas escholas para outras que mais precizem ou que nada possuão (...)”, seria possível amenizar a situação em que se encontrava o ensino municipal, relativa à falta de material e infraestrutura escolar. Ele sugeriu também a aquisição de quadros negros para exercícios de aritmética e de tinteiros de chumbo ou de vidro para as carteiras dos alunos. Esta recomendação aparentemente foi atendida pelo intendente, tendo em vista o ofício, já aqui trabalhado, do professor Lucio Casemiro dos Santos, que relatava justamente a retirada de mobília de sua escola para atender a outras e solicitava a mobília comprada nos Estados Unidos.

O segundo item estava relacionado à práxis dos professores, pois o delegado solicitava que fosse fornecida para cada uma das "39 escholas da Circunscripção" o que chamou de "escripturação escholar", ou seja, dados sobre a matrícula de alunos e mapas escolares, listas de presença e outros documentos que deveriam ser produzidos pelos docentes. Essa solicitação, entre outros fatores, poderia ajudar a explicar porque faltam, na documentação sob custódia do Arquivo Público do Município de Salvador (APMS), mapas escolares de alguns anos entre os que nos interessam neste estudo, prevalecendo somente aqueles referentes ao período de 1897 a 1900.

O terceiro ponto da lista tinha relação com o processo de escolarização moderno, que visava a controlar o tempo de trabalho nas escolas. O delegado escolar falava da necessidade de relógios e, nesta parte, foi preciso em suas instruções. Segundo ele, era imprescindível "que contrateis com alguma casa comercial, ou que mandeis vir directamente do estrangeiro, o fornecimento de relogios de parede para as escholas municipaes (...)". ${ }^{33}$ Importante lembrar que Ione Sousa (2008) defende que o relógio foi um dos mecanismos do processo de escolarização e da cultura escolar na Bahia do final do século XIX. Em nosso trabalho, concordamos e corroboramos a argumentação de Sousa, pois é latente que esse mecanismo perdurou no pós-abolição e começo da República. Segundo Araponga, seria preciso acabar com a situação rotineira que obrigava o professor a ocupar os alunos de vez em quando para olhar no relógio do vizinho, da botica ou da venda mais próxima. 
O quarto e último item da lista do delegado solicitava que fossem comprados compêndios elementares para os alunos, "como garante o Art. 50 da Lei do Ensino", para que, dessa maneira, os professores não pudessem mais se desculpar pelo baixo desempenho de seus pupilos. Araponga também instruiu como deveriam ser adquiridos tais materiais. Segundo ele, a compra deveria ser feita em pequenas quantidades e se limitar aos compêndios que fossem realmente necessários. Supomos que essas indicações buscavam poupar as finanças municipais, citadas recorrentemente como ínfimas. João Theodoro Araponga terminou seu texto garantindo que suas sugestões, caso fossem atendidas pelo intendente municipal, melhorariam, e muito, o ensino do município. Por último, ele defendeu seu professorado, assegurando que era habilitado e capaz de cumprir com os deveres que a legislação competente lhe impunha.

O segundo ofício que deteve nossa análise nesta pesquisa foi uma circular, assinada por ambos os delegados escolares, João Theodoro Araponga e Antonio Bahia da Silva Araujo, em 1899. Eles escreveram advertindo seus professores por terem abandonado suas escolas em dias letivos. O documento, intitulado "Circular aos Senres. Professores da $1^{a} e$ $2^{a}$ Circunscripção Escholar do Municipio da Capital"34, expressava uma tentativa de conservar os professores em sala de aula e mantê-los ensinando, de forma a evitar que se dedicassem a qualquer outra atividade. De acordo com Araponga e Araujo, o intendente municipal teria chamado a atenção, no dia 8 de março de 1899, para um "facto altamente censuravel" por parte de alguns de seus professores, ao:

(...) abandonarem suas escholas, e ostensivamente se apresentarem nos logares mais publicos da Capital, como em menos preço das autoridades do serviço do ensino, e esquecimento por completo de seus deveres, ficae advertidos de que serão rigorosamente punidos nos termos das leis em vigor e todos quanto incorram em semelhantes faltas ${ }^{35}$ [grifos nossos].

Com a ajuda da legislação da época, podemos analisar o que não seria permitido aos professores públicos primários. Como sabemos, essa circular foi enviada aos professores no dia 14 de março de 1899. Neste caso, a legislação correspondente era a do ano de 1895, o Ato de 4 de outubro, nos seus artigos $42^{\circ}, 48^{\circ}$ e $51^{\circ}$, que apontam as proibições aos professores: Occupar-se ou occupar os alumnos em qualquer mistér estranho à sua profissão; $b$ ) Ausentar-se da cadeira durante o anno letivo sem licença; c) Corresponder-se com as auctoridades superiores de ensino sem por intermedio do Delegado Escolar (...). ${ }^{36}$ No mesmo ato estavam dispostas as punições, caso os docentes incorressem em alguma das proibições acima. Essas variavam desde uma advertência, uma remoção, até uma possível intervenção por parte da Intendência Municipal. Os delegados escolares poderiam advertir seu professorado em particular ou em público, e as diferentes autoridades do serviço de ensino municipal teriam o poder para aplicar as punições mais severas. De acordo com o Ato de 4 de outubro de 1895, se aplicavam as seguintes penas: a) Advertencia particular ou publica; b) Suspensão. c) Remoção; d) Interdição. ${ }^{37}$

No caso do ofício supracitado, a advertência foi direcionada a todos os professores públicos do município da capital do estado da Bahia. Estariam essas faltas, ou abandono do trabalho por parte dos docentes, relacionadas a outras atividades que estes poderiam estar exercendo para ampliar seus rendimentos? $\mathrm{Na}$ circular, os delegados deixaram claro que as ausências sem licença tornaram-se ostensivas, sendo cometidas por vários professores, e que estes eram vistos nos lugares mais públicos. Araponga e Araujo solicitaram que, quando fosse realmente necessária a falta, esta fosse avisada com o máximo de antecedência para que fosse providenciada a devida substituição. Advertiram também que estariam "cessando desde já a pratica abusiva de se julgarem os Senres. professores com direito a duas faltas 
mensaes independentemente de participação ou licença (...)". ${ }^{38}$ Esses dois dias no mês constituiriam algum tipo de tradição ou costume até então tolerado pela fiscalização do ensino primário? Caso assim fosse, poderíamos tomá-los, nas palavras de Edward Thompson, como a "interface" com o que estaria normatizado, a "práxis" em contrapartida da norma (THOMPSON, 1998, p. 86).

Um professor público primário muito atuante durante o período aqui pesquisado constou como regente da $1^{\mathrm{a}}$ cadeira masculina do distrito do Santo Antônio além do Carmo. Raymundo Cardozo Gomes, para além de ser regente e responsável por uma escola pública primária, foi mais um dos que apareceram contribuindo para a Revista do Ensino Primário nos anos de 1892 e 1893. Em 1900, ele elaborou um discurso muito prolixo, mas ao mesmo tempo revelador. Sua fala ${ }^{39}$ começou fazendo um chamado para que adentrassem àqueles que em nada acreditassem, àqueles que questionassem. Nas palavras do professor: "Entrae ah vós! vós que pertenceis ao numero dos scepticos, vós que em nada credes e que de tudo duvidaes; entrae". ${ }^{40}$ Tentava assim instigar a atenção de seus ouvintes sobre o que viria a dizer a respeito da instrução primária na Salvador do pós-abolição. Para esse professor, o estado da Bahia e a sua capital, a "Athenas Brasileira" em suas palavras, eram lugares de heróis, águias valentes e gênios. Quando escreveu sobre a educação, Raymundo Gomes relatou que “(...) na Bahia, é pena dizel-o, porém, infelizmente, a instrucção primaria é mais um mytho do que uma realidade." ${ }^{11} \mathrm{O}$ docente continuou sua crítica abordando a temática da administração do ensino.

O professor teria se referido à instrução pública primaria baiana como um "mito" por conta da diferença marcante entre a legislação e a situação do ensino público primário. Seguindo a linha de críticas que encontramos nas publicações de 1892 e 1893 da Revista do Ensino Primário, inferimos que se estabeleceu uma relação de distância entre o que deveria ter sido e o que foi de fato. Observamos através da leitura do discurso que, para o autor, seria vontade consciente do governo deixar o povo "escravo às suas paixões". Tal fato poderia representar um possível desejo das autoridades republicanas em controlar a população pobre e carente de acordo com os projetos políticos dominantes. Além disso, quando Raymundo Gomes criticou todas as reformas educacionais, desde a de 1870 até a de 1895, consideradas "partos escandalosos do patronato", provavelmente estava defendendo os interesses de parte do professorado soteropolitano.

Discursos como esse, dos professores que eram vinculados à Revista do Ensino Primário, deixaram a entender que os projetos das elites governantes foram, no mínimo, malfadados por não terem saído do papel. Seguindo essa linha de raciocínio, seria possível concluir que, enquanto agente histórico, a revista se constituiu como a "voz" de uma parcela do professorado de Salvador. Essa voz fazia uma oposição incansável aos órgãos públicos da administração escolar e ressaltava a enorme dificuldade que o corpo docente tinha de superar para instruir aos "filhos do povo" - forma como foram chamados os alunos e alunas das escolas públicas primárias. Esses docentes estavam comprometidos com a construção de uma determinada representação da situação das escolas públicas primárias. Para tal, certamente foram necessárias lutas, tensões e embates no intuito de defender interesses do professorado, principalmente aqueles voltados para uma maior autonomia, melhorias na infraestrutura e qualificação superior dos inspetores escolares.

\section{Conclusões.}

Neste artigo, nosso objetivo foi o de contribuir com os estudos sobre a escolarização e a cultura escolar no pós-abolição, na cidade do Salvador. Analisamos a relação entre trabalho urbano, raça e instrução pública, por meio do cruzamento de dados censitários com a bibliografia especializada. Em seguida, nos debruçamos sobre dados relacionados à 
escolarização e à cultura escolar relativos à instrução pública, tais como número de escolas e de alunos, aproveitamento e procedimento destes discentes, entre outros. Privilegiamos algumas experiências de professores, delegados escolares, famílias, estudantes ${ }^{42} \mathrm{e}$ comunidade, por meio das tensões e embates existentes no processo de escolarização.

Com essa operação, pudemos perceber como a cultura escolar entrava em conflito com a cultura urbana e com o mundo do trabalho. Pesquisamos dados relativos a matrícula, freqüência e alunos prontos, cruzados com informações sobre faixa etária, para tentar identificar a presença de meninos e meninas nas escolas, supondo que muitos deles, presentes ou ausentes, já estariam inseridos em atividades laborais e ofícios. Para isso, analisamos relatórios de professores e delegados escolares, nos quais apareceram diversas informações sobre as condições materiais e imateriais das escolas.

Por último, nos debruçamos sobre os dados contidos nos mapas escolares encontrados no acervo. Nossa tarefa foi a de comparar as informações produzidas pelos professores públicos primários com aquelas obtidas por meio da legislação ou dos agentes da fiscalização e administração escolares.

\section{Bibliografia.}

ALBUQUERQUE, Wlamyra R. de. O jogo da dissimulação: abolição e cidadania negra no Brasil. São Paulo: Companhia das Letras, 2009.

ANANIAS Mauricéia. Propostas de educação popular em Campinas: “As aulas noturnas". Campinas,SP: Cadernos Cedes, ano XX, no 51; novembro/2000.

BARROS, Surya A. Pombo de. Negrinhos que por ahi andão: a escolarização da população negra em São Paulo (1870-1920). Dissertação de mestrado. São Paulo, FaE/USP, 2005.

CASTELLUCCI, Aldrin A. Silva. Trabalhadores, máquina política e eleições na Primeira República. Salvador: UFBA/FFCH (tese de doutorado), 2008.

CAVAlCANTE, Ian A. Pela instrucção dos filhos do povo: escolarização e cultura escolar na Salvador do pós-abolição, 1888-1906. Dissertação (Mestrado em Educação). FaE/PPG-Educ UFF: Niterói-RJ, 2015, 195p.

CERTEAU, Michel de. A Escrita da História. Rio de Janeiro: Editora Forense Universitária, 2002.

CHALHOUB, Sidney. Cidade febril: cortiços e epidemias na Corte imperial. São Paulo: Companhia das Letras, 1996.

DANTAS, Carolina Vianna. Racialização e mobilização negra nas primeiras décadas republicanas. In: Cadernos PENESB - FEUFF, n 12. Niterói: Ed. Alternativa/EdUFF, 2010, pp. 141-152.

FARIA FILHO, Luciano Mendes de. Educação pública: a invenção do presente. Belo Horizonte: Mazza Edições, 2012.

FERREIRA FILHO, Alberto Heráclito. Desafricanizar as ruas: elites letradas, mulheres pobres e cultura popular em Salvador (1890-1937). Afro-Ásia, no 21-22, 1998-1999, pp. 239-256.

FRAGA FILHO, Walter. Encruzilhadas da liberdade: histórias e trajetórias de escravos e libertos na Bahia, 1870 - 1910. Tese de Doutorado em História - UNICAMP: Campinas, 2004.

Mendigos, moleques e vadios na Bahia do Século XIX. São Paulo: Hucitec; Salvador: EDUFBA, 1996.

GOMES, Flavio dos Santos. Negros e política(1888-1937). Rio de Janeiro: Jorge Zahar Ed., 2005. 
LARA, Silvia Hunold. Introdução: a história social e o racismo. In: Dossiê racismo: história e historiografia. História Social, n. 19, segundo semestre de 2010.

MATTOS, Marcelo Badaró. E. P. Thompson e a tradição de crítica ativa do materialismo histórico. Rio de Janeiro: Editora UFRJ, 2012.

MATTOS, Hebe Maria e RIOS, Ana Lugão. Memórias do cativeiro: família, trabalho e cidadania no pós-abolição. Rio de Janeiro: Civilização Brasileira, 2005.

MENEZES, Jaci Maria Ferraz de. A República e a construção do direito à educação na Bahia. In: SANTANA, Elizabete Conceição et al (Orgs.). A construção da escola primária pública na Bahia: guia de referências temáticas nas leis de reforma e regulamentos, 18901930. Salvador: EDUFBA, 2011. pp. 17-29.

NOGUEIRA, Maria Alice; NOGUEIRA, Claudio M. Martins. Bourdieu e a Educação. 3 ed. Belo Horizonte: Autêntica, 2009.

OLIVEIRA, Marcus Aurélio Taborda de; MEURER, Sidmar dos Santos. Tensões entre o prescrito e o realizado na escolarização paranaense na década inicial do século XX: experiências de professores primários a partir da análise dos relatórios da instrução pública. In: OLIVEIRA, Marcus Aurélio Taborda de (org.). Cinco estudos em História e Historiografia da Educação. Belo Horizonte: Autêntica, 2007.

PAIXÃO, Lea Pinheiro. Compreendendo a escola na perspectiva das famílias. In: MULLER, Maria Lúcia e PAIXÃO, Lea Pinheiro (Orgs.). Educação, diferenças e desigualdades Cuiabá: EdUFMT, 2006.

PEREIRA, Amilcar Araujo. O mundo negro: relações raciais e a constituição do Movimento Negro no Brasil. Rio de Janeiro: Pallas: FAPERJ, 2013.

REIS, João José. De olho no canto: trabalho de rua na Bahia na véspera da abolição. AfroÁsia, no 24, 2000, pp. 199-242.

SANTOS, Mário Augusto da Silva. A República do povo: sobrevivência e tensão. Salvador: EDUFBA, 2001.

SCHUELER, Alessandra F. M. de. Projetos de educação em disputa no período da abolição e pós-abolição (1870 - 1910): intelectuais negros, imprensa e reformas sociais no Rio de Janeiro, Projeto de pesquisa, UFF, 2011.

SCHUELER, Alessandra; RIZZINI, Irma. Escolarização de meninos e meninas na Capital Federal no pós-abolição (1888-1910). In: XI Congresso Iberoamericano de História da Educação Latinoamericana: Sujetos, poder y disputas por la educación. XI Congresso Iberoamericano de História da Educação Latinoamericana. Toluca: Colégio Mexiquense, 2014. v. 0. p. 1-18.

SENRA, Nelson. História das Estatísticas Brasileiras: 1822-2002. Vol. 1 e 2. Rio de Janeiro: IBGE, 2006.

SILVA, Maria Conceição B. da Costa e. O ensino primário na Baia: 1889 - 1930. (Tese de Doutorado) Salvador: Faced/UFBA, 1997.

SOUSA, Ione Celeste de. Prover as aulas, regular o Tempo: uma leitura sobre cultura escolar na Bahia oitocentista. In: LUZ, José Augusto e SILVA, José Carlos (Orgs.). História da educação na Bahia. Salvador: Arcadia, 2008.

. Escolas ao Povo: experiências de escolarização de pobres na Bahia - 1870 a 1890. Tese de Doutorado em História Social, PEPGHS, PUC/São Paulo; 2006.

THIN, Daniel. Famílias de camadas populares e a escola: confrontação desigual e modos de socialização. Trad. de: Janine Françoise AndreéHounard. In: MULLER, Maria Lúcia e PAIXÃO, Lea Pinheiro (Orgs.). Educação, diferenças e desigualdades. Cuiabá: EdUFMT, 2006. 
THOMPSON, Edward P. Folclore, Antropologia e História Social. In: THOMPSON, Edward P. As peculiaridades dos ingleses e outros artigos. Campinas: Ed. Unicamp, 2012.

A formação da classe operária Inglesa, v. I: a árvore da liberdade. Tradução de Denise Bottmann. 6 ed. São Paulo: Paz e Terra, 2011.

Costumes em comum: estudos sobre a cultura popular tradicional. São Paulo: Companhia das Letras, 1998.

A miséria da teoria ou um planetário de erros: uma crítica ao pensamento de Althusser. Tradução de Waltensir Dutra. Rio de Janeiro: Zahar Editores, 1981.

VIANA, Larissa. O idioma da mestiçagem: as irmandades de pardos na América Portuguesa. Campinas, SP: Editora da UNICAMP, 2007.

VIDAL, Diana Gonçalves. Faces da obrigatoriedade escolar: lições do passado, desafios do presente. In: VIDAL, Diana Gonçalves; SÁ, Elizabeth Figueiredo de; SILVA, Vera Lúcia Gaspar da. Obrigatoriedade escolar no Brasil. Cuiabá: EdUFMT, 2013.

Mapas de freqüência a escola de primeiras letras: fontes para uma história da escolarização e do trabalho docente em São Paulo na primeira metade do século XIX. Revista Brasileira de História da Educação, n. 17, mai/ago. 2008.

VILLELA, Heloisa de O. S. A trajetória de um professor negro no Brasil escravocrata. In: OLIVEIRA, Iolanda de (Org.). Relações raciais no contexto social, na educação e na saúde: Brasil, Cuba, Colômbia e África do Sul. Rio de Janeiro: Quartet: 2012.

Acervos pesquisados.

Arquivo Público do Município de Salvador (APMS).

Arquivo Público do Estado da Bahia (APEB).

Biblioteca Pública do Estado da Bahia (BPEB).

Hemeroteca Digital da Biblioteca Nacional (BN).

Núcleo de Pesquisa em História Econômica e Demográfica (NPHED).

\footnotetext{
${ }^{1}$ Experiência humana enquanto homens e mulheres não como "indivíduos livres" ou sujeitos autônomos, "mas como pessoas que experimentam" suas "relações produtivas determinadas" enquanto necessidades, interesses e antagonismos. A experiência é gerada na "vida material", e não pode ser determinada ou prevista, e com ela a "estrutura é transmutada em processo e o sujeito é reinserido na história". Ver: Edward P. Thompson (1981).

${ }^{2}$ Perspectiva historiográfica que valoriza as experiências dos sujeitos, a agência e a tradição crítica ativa no campo do materialismo histórico. Ganha notoriedade a partir do grupo de historiadores britânicos conhecido por New Left, que contou com renomados pesquisadores, como Edward Thompson, Raymond Williams e Eric Hobsbawm. Ver: Marcelo Badaró Mattos (2012).

${ }^{3}$ APMS. Mappa mensal de alumnos da Escola Municipal do Sexo Masculino do Districto da Conceição da Praia, do mês de fevereiro, ano de 1898. Fundo: Intendência Municipal, Seção: Ensino Municipal; Diretoria de Ensino Municipal: Mapas, Anuais, Ofícios, Freqüências, Processos 1889 - 1910, caixas: 01 a 23.

${ }^{4}$ Utilizamos este conceito seguindo as proposições teóricas de Edward Thompson, no que se refere ao fazer-se da classe operária. Acreditamos que assim como essa se fez, a escolarização e a cultura escolar passaram por um processo similar. Ver: Thompson (2011).

${ }^{5}$ Dados encontrados na página web do Núcleo de Pesquisa em História Econômica e Demográfica (NPHED) da Faculdade de Educação $(\mathrm{FaE})$ da Universidade Federal de Minas Gerais (UFMG): http://www.nphed.cedeplar.ufmg.br/pop72/index.html Acesso em 02 de janeiro de 2014.

${ }^{6}$ Raça não como conceito biológico, mas sim enquanto uma construção sócio-histórica, baseada nas diferenças físicas entre os seres humanos. Tais diferenças, neste trabalho, não são consideradas de maneira hierarquizada, indo ao encontro de uma visão racialista, segundo a qual não existiram raças melhores ou piores, mas somente diferentes. Ver: Wlamyra Albuquerque (2009), Silvia Lara (2010), Amilcar Pereira (2013).

7 Nomenclatura utilizada para denominar trabalhadores urbanos, principalmente das áreas comerciais e portuárias da cidade, que se dedicavam a trabalhos braçais diversos a exemplo de carga e descarga. Esses trabalhadores eram em sua maioria negros, africanos ou nascidos no Brasil, escravos ou libertos.
} 
Organizavam-se em grupos chamados de cantos, que também representavam sua localização, e essa prática se manteve após a abolição. Para ampliar o conhecimento sobre esse assunto ver: João José Reis (2000).

${ }^{8}$ Para ampliar o conhecimento sobre as aulas noturnas para adultos na Bahia, no último quartel do século XIX, ver: Ione Sousa (2006).

${ }^{9}$ Para aprofundar sobre esta questão, ver: Ione Sousa (2006), Mário Augusto da Silva Santos (2001) e João José Reis (2000).

${ }^{10}$ Nomenclatura utilizada para se referir ao local onde se situava um grupo de ganhadores, para oferecer seus serviços. Ver: João José Reis (2000).

${ }^{11}$ APEB. Aula primaria nocturna estabelecida à rua do Silva na freguesia de Santo Antonio em 11 de Junho de 1888. Bahia, 19 de Junho de 1888, Antonio José de Moraes, professor publico. Seção: Arquivo Colonial e Provincial Governo da Província, Instrução Pública, Ensino Elementar, Mapa de Alunos, 1848-1888, maço nº 4001.

12 Aqui não consideramos o conceito de mestiço somente como uma "mistura" de diferentes raças, mas sim enquanto um processo carregado de "conotações sociais". Ou seja, seria um movimento hierárquico com relações de poder e expressão na política, religião ou legislação, que seria capaz de influenciar as relações cotidianas dos indivíduos que viveram em sociedades escravistas. Ver: Larissa Viana (2007).

${ }^{13}$ Ver: Ian Cavalcante (2015), Ione Sousa (2006), Walter Fraga Filho (2004) e Maria Conceição B. da Costa e Silva (1997).

14 APMS. Relação das escholas municipaes da capital com a declaração dos Logares em que se acham colocadas procedido em 1870. Ver: Fundo: Intendência Municipal, Seção: Ensino Municipal; Diretoria de Ensino Municipal: Ofícios e Requerimentos caixa 20.

${ }^{15}$ APMS. Municipio da Capital do Estado da Bahia: Mappa do professorado municipal em exercício para o ano de 1897. Ver: Fundo: Intendência Municipal, Seção: Ensino Municipal; Diretoria de Ensino Municipal: Ofícios e Requerimentos caixa 20. Esta foi a nomenclatura utilizada para separar as escolas públicas primárias da cidade do Salvador em duas grandes áreas que compreendiam diferentes distritos. Na $1^{a}$ circunscripção, constavam os distritos da Sé, São Pedro, Sant'anna, Vitória, Brotas, Itapoan, Cotegipe, Paripe, e mais um que a documentação não permitiu a leitura. Já na $2^{a}$ circunscripção, apareciam os da Conceição da Praia, Rua do Passo, Santo Antônio além do Carmo, Pilar, Mares, Penha, Pirajá, Passe e Matuin.

${ }^{16}$ APMS. Mappa das escholas que se achão funcionando nos seis distritos urbanos da $2^{a}$ Circunscripção Litteraria do Municipio da Capital da Bahia. Elaborado pelo Delegado Escolar João Theodoro Araponga, 20 de junho de 1896. Ver: Fundo: Intendência Municipal, Seção: Ensino Municipal; Diretoria de Ensino Municipal: Ofícios e Requerimentos, caixa 01.

${ }^{17}$ APMS. Relatorio enviado ao Conselho Municipal pelo Professor Prisciliano José Leal - Delegado interino da $2^{a}$ Circunscripção escolar, relativamente ao ensino primário durante o $1^{o}$ do corrente anno. Bahia, Julho de 1902. Ver: Fundo: Intendência Municipal, Seção: Ensino Municipal; Diretoria de Ensino Municipal: Processos, caixa 03.

${ }^{18}$ APMS. Bahia e $2^{a}$ Circunscripção Litteraria do Municipio da Capital, 20 de junho de 1896. Relatório do Delegado Escolar Professor João Theodoro Araponga, sobre o estado das escolas no momento em que a municipalidade assume a responsabilidade sobre as escolas públicas primárias. Ver:Fundo: Intendência Municipal, Seção: Ensino Municipal; Diretoria de Ensino Municipal: Ofícios e Requerimentos caixa 01.

19 APMS. Relação dos alumnos promctos das escolas da $2^{a}$ Circunscripção, sem data e sem assinatura. Acreditamos que seja no nosso recorte temporário, pois estava junto à outra documentação pertencente aos anos entre 1896 e 1900, além de constarem somente os distritos que existem no recorte em questão, e os nomes de alguns professores serem os mesmos vistos em outros documentos do contexto trabalhado. Ver: Fundo: Intendência Municipal, Seção: Ensino Municipal; Diretoria de Ensino Municipal: Ofícios e Requerimentos caixa 01 .

${ }^{20}$ APMS. Annexo $N^{o} 2$ Escolas que deram alumnos a exames finaes, Ano de 1902. Ver:Fundo: Intendência Municipal, Seção: Ensino Municipal; Diretoria de Ensino Municipal: Ofícios e Requerimentos caixa 01.

${ }^{21}$ APMS. $1^{a}$ Aula Municipal do Distrito de Santo Antonio. Relatório de visitas do Delegado Escolar João Theodoro Araponga, nos anos de 1896 e 1897. Ver:Fundo: Intendência Municipal, Seção: Ensino Municipal; Diretoria de Ensino Municipal: Ofícios e Requerimentos, caixa 01.

22 Documentação encontrada no Arquivo Público Municipal de Salvador (APMS), Fundo: Intendência Municipal, Seção: Ensino Municipal; Diretoria de Ensino Municipal: Mapas, Anuais, Ofícios, Freqüências, Processos 1889 - 1910, caixas: 01 a 23.

${ }^{23}$ BAHIA. Ato de 18 de agosto de 1890 (Art. $29^{\circ}$ a $32^{\circ}$ ).

${ }^{24}$ BAHIA. Lei de 24 de agosto de 1895 (Art. $\left.2^{\circ}, 5^{\circ}, 8^{\circ}\right)$. 
${ }^{25}$ APMS. Ofício ao Illmo. e Ex. Sñr. Dr. Intendente do Municipio desta Capital, Bahia 10 de Fevereiro de
1900. Abaixo assinado por alunos solicitando a permanência do professor Raymundo Cardoso Gomes. Ver:
Fundo: Intendência Municipal, Seção: Ensino Municipal; Diretoria de Ensino Municipal: Ofícios e
Requerimentos caixa 20 .
26 No documento supracitado constam 25 alunos, segue aqui a lista completa de seus nomes: Euclides
Lamartine Pereira Caldas, Alvaro da Silva Bahia, Pedro Advincula Rogerio, João do Rego Gomes, Aristobulo
dos Santos Gomes, Oscar Mathias da Paixão, Affonso Diniz Caldas, Frederico Antonio da Silva Porto,
Claudionor Eduardo de Lima, Octaciano Carlos Fernandes, Juvencio Bransford Cardoso, Manoel Cosme
Coelho Borges, Francisco Xavier Ferreira Dias, Ambrosino Gonçalves da Silva, Felippe Osvaldo da Silva
Machado, Juvencio Gonçalves da Silva, Affonso Ferrer Coitinho, Mauricio de Meirelles, José Guilherme,
Cleobulo dos Santos Gomes, Hugo de Castro, Empirio de Castro, Eugenio de Souza Maciel, Pedro Luiz,
Vianna. ${ }^{27}$ APMS. Ofício ao Illmo. e Ex. Sñr. Dr. Intendente do Municipio desta Capital, Bahia 15 de Maio de 1900.
Abaixo assinado por moradores denunciado atos imorais cometidos pelo professor municipal Manoel Thiotimio de Almeida. Ver: Fundo: Intendência Municipal, Seção: Ensino Municipal; Diretoria de Ensino Municipal: Ofícios e Requerimentos caixa 20.

${ }^{28}$ Neste ponto, nos referimos ao lugar social que cada agente ocupa, tanto os sujeitos históricos como os próprios historiadores, os quais também pertencem a um determinado lugar social de produção e escrita da História. Ver: Michel de Certeau (2002).

${ }^{29}$ Aqui utilizamos os conceitos elaborados por Pierre Bourdieu para quem o capital cultural representa as qualificações intelectuais produzidas e perpassadas pela instituição familiar e pela instituição escolar. O capital social se refere ao conjunto de relações que são úteis ao sujeito, indivíduo ou grupo social, no decorrer de sua trajetória. E, por sua vez, o capital econômico está relacionado a qualquer tipo de renda, salário ou recurso patrimonial. Ver: Maria Alice Nogueira e Claudio Martins Nogueira (2009).

${ }^{30}$ Termo utilizado por Daniel Thin (2006) para definir as famílias provenientes das classes menos abastadas.

${ }^{31}$ AMPS. Ofício ao Illmo e Ex. SñrDr Intendente do Municipio desta capital, Bahia e $1^{a}$ CircunscripçãoEscholar do Municipio, 12 de Abril de 1897. Ofício do professor Delegado Escolar João Theodoro Araponga sugerindo ações a respeito da instrução pública primária no intuito de melhorá-la. Ver: Fundo: Intendência Municipal, Seção: Ensino Municipal; Diretoria de Ensino Municipal: Ofícios e Requerimentos caixa 20.

${ }^{32}$ Idem.

33 Idem.

${ }^{34}$ APMS. Circular aos Senres. Professores da $1^{a}$ e $2^{a}$ CircunscripçãoEscholar do Municipio da Capital, Bahia, 14 de março de 1899. Redigido pelos Delegados Escolares João Theodoro Araponga e Antonio Bahia da Silva Araujo, enviado aos professores contendo uma advertência contra o abandono de trabalho. Ver: Fundo: Intendência Municipal, Seção: Ensino Municipal; Diretoria de Ensino Municipal: Ofícios e Requerimentos caixa 20.

${ }^{35}$ Idem.

${ }^{36}$ BAHIA, Ato de 4 de outubro de 1895 (Art. $42^{\circ}, 48^{\circ}$ e $51^{\circ}$ ).

${ }^{37}$ Idem.

${ }^{38}$ APMS. Circular aos Senres. Professores da $1^{a}$ e $2^{a}$ CircunscripçãoEscholar do Municipio da Capital, Bahia, 14 de março de 1899. Redigido pelos Delegados Escolares João Theodoro Araponga e Antonio Bahia da Silva Araujo, enviado aos professores contendo uma advertência contra o abandono de trabalho. Ver: Fundo: Intendência Municipal, Seção: Ensino Municipal; Diretoria de Ensino Municipal: Ofícios e Requerimentos caixa 20.

${ }^{39}$ APMS. Discurso proferido pelo professor Raymundo Gomes, por ocasião da distribuição de premios $e$ diplomas aos alumnos das escolas publicas municipaes, na exposição escolar realisada a 2 de Dezembro de 1900, no Theatro S. João. Ver: Fundo: Intendência Municipal, Seção: Ensino Municipal; Diretoria de Ensino Municipal: Ofícios e Requerimentos caixa 20.

${ }^{40}$ Idem.

${ }^{41}$ Idem.

Recebido: $\quad$ março-16 Aprovado: setembro-16 